\title{
Poverty and Economic Inequalities in Peru during the Boom in Growth: 2004-14
}

\author{
Javier Herrera
}

\begin{abstract}
In the first decade of the twenty-first century, Latin America experienced strong growth that was primarily attributable to high export prices and growing demand from China. Moreover, democratic transitions in the region brought to power governments with highly contrasting economic policies and different visions of the sectors that were driving growth. These governments also differed in terms of the social policies they implemented to combat poverty and inequality. Countries with 'heterodox' policies (Brazil, Ecuador, Bolivia, Argentina and Venezuela) that promoted efforts to better distribute the fruits of growth increased social expenditure and encouraged, to a greater or a lesser degree, productive diversification, particularly in the internal market. Countries with 'orthodox' policies (Chile, Colombia and Peru) promoted foreign investment in the primary export sector (mining, oil, fishing, soybean cultivation, etc.), which was considered the main driver of growth, and implemented conservative fiscal and monetary policies that created a climate of confidence for investors and led to stable exchange rates and prices.

This chapter attempts to assess the events of the last decade in terms of distributive aspects by comparing the cases of countries that applied heterodox policies with those that implemented orthodox policies. The study focuses primarily on Peru, where governments combined a 'leftist' ideology—which brought them to power-with economic policies that were close to the 'Washington Consensus'. The author examines the results of this phase of rapid growth in terms of poverty reduction and assesses to what extent these results have been accompanied by (and possibly have been achieved thanks to) a drop in inequality and the growth of the middle class. This phenomenon is seen by some as a guarantor of political stability and by others, as a cauldron of conflict. Finally, the degree to which social expenditure and taxation can play distributive roles in this new phase of slower growth is explored.
\end{abstract}




\section{Introduction}

During the first decade of the new millennium, Latin America posted strong growth. This was due primarily to higher prices for exports coupled with growing demand from China. This led to surpluses in external accounts but also generated a significant reduction in the fiscal deficit and allowed public expenditure to be increased. Countries with 'heterodox' policies (Brazil, Argentina, Ecuador, Bolivia and Venezuela) promoted efforts to better distribute the fruits of growth by increasing social expenditure and encouraging, to a greater or lesser degree, productive diversification, particularly in the internal market. Countries with 'orthodox' policies (Chile, Colombia and Peru) promoted foreign investment in the primary export sector (mining, oil, fishing, soybean, etc.), which was considered the main driver of growth, and implemented conservative fiscal and monetary policies. This created a climate of confidence for investors and led to stable exchange rates and prices. A deterioration in the terms of trade and a downturn in exports to China, which began in 2010, has blocked expansion in the region, and growth levels are close to zero in some cases and negative in others.

After having experienced rapid growth throughout the expansion cycle that accompanied the boom in commodity prices, Latin American economies, and in particular those that are the most dependent on raw material exports (mainly oil, metals and soybean) to China, have suffered a brutal drop in their growth rates. After three years of weak growth, in 2015 growth in Latin America turned negative (-0.9 per cent). Some countries, including Brazil, Venezuela and Ecuador, have reported negative growth rates, while the downturn has - with a few exceptions - spread to the other countries of the region (World Bank, 2016). The perspectives for growth are not encouraging according to the forecasts published by both the World Bank (World Bank, 2016) and the International Monetary Fund (IMF) (IMF, 2016), and indicate that a growth phase characterised by relatively moderate growth is on the horizon.

During the decade of sustained growth, various countries implemented active policies to combat poverty (conditional cash transfers) and increased social expenditure, which widened access to education and health. In this period, Latin America was the region that posted the most significant reductions in poverty (Inchauste et al., 2014). Nevertheless, and despite macroeconomic performance (or perhaps thanks to it) and a drop in poverty, the highest rates of inequality in the region have fallen only moderately and continue to be among the highest in the world (de Ferranti et al. 2004; Gasparini et al., 2009). ${ }^{1}$

1 Diagnosing the evolution of inequality in Latin America in the last decade is subject to several methodological limitations linked to problems with household surveys in terms of 
The drop in exports has led the currency position to fall, causing depreciation in the exchange rate and inflationary pressures. These inflationary pressures have, in turn, eaten away at household purchasing power, which has attenuated the pace of poverty reduction. Private investments have fallen and some countries have adopted restrictive fiscal policies, which has further exacerbated the economic downturn. In this new context, it is important to examine the impact that the downturn/recession has had on inequalities (de la Torre et al., 2014).

Although social expenditure targeting the poor also grew during the expansive phase, which to a certain extent reconciled growth with redistribution, during the current period of lower growth it is not feasible to expect that expansion alone will reduce poverty and inequality. Nevertheless, there is still a wide margin for redistributive policies given that social expenditure remains very low and progressive direct taxes, unlike in developed countries, play a much less important if not an insignificant role in reducing inequalities. This requires a great deal of political willingness, and a social consensus must be in place to back these policies.

The different governments that have set up shop in Peru since 1990 have chosen to implement neo-liberal policies, which include suppressing or reducing the role of state enterprise while making the job market more flexible. The primary-exporter model has not been questioned and on the contrary moves have been made to promote foreign investment in the mining and oil sectors, where profitability has risen due to high international prices. Weak productive diversification has focused on exporting non-traditional products, most of which are agricultural and generated by large, high-technology farming interests.

This chapter is divided into thirteen sections. Section 2 examines the contrasting evolutions of poverty, inequality and polarisation in countries that apply heterodox policies versus those that implement orthodox approaches by breaking down the main microeconomic factors that drive these evolutions in each context. In the third section, and in those that follow, we will examine the case of Peru, where macro orthodox policies are combined with micro 'heterodox' policies. Based on a first-hand analysis of household surveys for the last 12 years, we study the behaviour of poverty during the different stages of growth (Section 3) and answer the question of the extent to which growth was propoor by highlighting the contrasts between the period of rapid growth and the period of deceleration (Section 4). In Section 5 we examine how the national

estimating non-labour income without bias and impediments to capturing information for the highest income percentiles (Bourguignon, 2015; Ravallion, 2016; Yamada et al., 2012). 
macroeconomic situation (linked to exchange rate depreciation) and the situation on the international front (boom in raw material prices; strong demand) made their mark through price increases, for food in particular.

The reduction in poverty has lifted a large number of households from the throes of hardship, but the question is to what extent has this population become part of the 'new middle class' or has this group merely increased the numbers of vulnerable individuals who are on the verge of falling back into poverty? This point will be addressed from a dynamic perspective (poverty transitions) in Section 6, and from a static perspective through indicators of inequality and polarisation (Sections 8 and 9). In Section 7, we will examine the (direct) role played by public transfer policies in reducing poverty. In Section 10, we will examine the sources of income that account for changes in income inequality. The perception of inequality and the role of the state in redistribution leads to the formation of political coalitions that favour more state intervention through redistributive policies to reduce inequalities. This topic, which is particularly relevant in the current situation of a change of administration, will be discussed in Section 11 through an analysis of the opinion surveys from Latinobarómetro and the World Values Survey. Finally, in the last section we will explore the extent to which fiscal policy, through progressive direct taxes, can serve as a redistributive instrument to reduce income inequalities while generating resources for social policies that favour the poor.

\section{Evolution of Poverty and Inequality in Latin America}

Judging by the noteworthy reduction in poverty levels, the last ten years have not been a 'lost decade' for the countries in the region. All of the countries studied, both those that apply 'heterodox' policies (Brazil, Argentina, Ecuador and Bolivia) and those that implement policies inspired by the Washington Consensus, saw their poverty levels fall by nearly half (Figure 8.1), with the notable exceptions of Chile and Argentina, which posted reductions of

2 In this section, we use poverty and inequality indicators from the SEDLAC database. The primary sources of data are as follows: Bolivia, 2003 is in fact 2002; Argentina, EPHC 2003-12 is the average of the first and second half years; Brazil, Nueva PNAD 2003, 2004-13 including the northern rural region; Peru, ENAHO; Colombia, ECH 2004-05, GEIH 2008-13; Ecuador, ENEMDU. This database was homogenised in the construction of the aggregate incomes as well as the values of the poverty lines (USD 4 in purchasing power parity (PPP) from 2005). We decided not to use ECLAC's indicators given the existence of a number of methodological problems and the lack of detailed information regarding imputations (Bourguignon, 2015). 


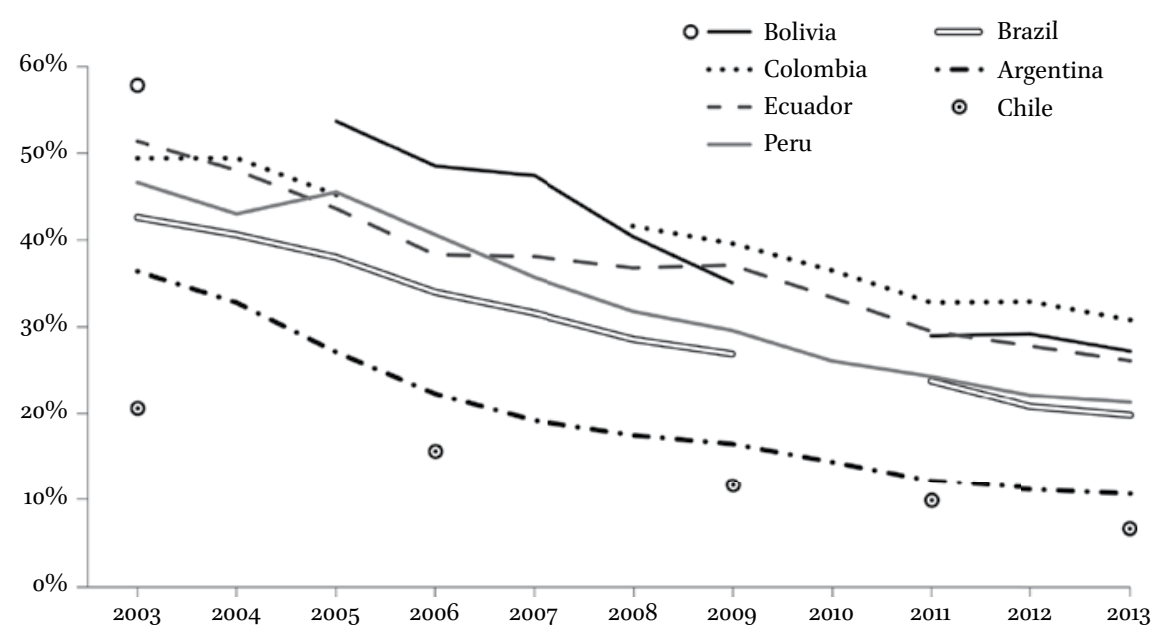

FIGURE 8.1 Evolution of poverty (USD 4 purchasing power parity, 2005), 2003-13. SOURCE: SEDLAC DATABASE.

67 per cent and 70 per cent, respectively, despite having followed very different orientations with regard to economic policy. Brazil and Peru, despite differences in policy orientations, have posted a very similar evolution in their incidences of poverty. Regardless of the fact that we still do not have harmonised data from the last two years, the figures published by the national institutes of statistics, although not comparable in terms of poverty levels, lead us to believe that poverty levels basically stopped falling in 2013, although we have yet to see a reversal of the downward trend. ${ }^{3}$ Looking beyond economic policies and the international context, the initial conditions of inequality affect the extent to which growth can reduce inequality. As such, social policies that combine poverty reduction and inequality reduction can be more successful than policies that seek simply to promote growth by creating favourable conditions for private investment.

Latin America, rightly, has the reputation for being the continent with the highest income inequality in the world (de Ferranti et al., 2004). Thanks to a decade of strong growth, different governments in the region have had the opportunity to implement redistributive policies to reduce inequalities (Lopez-Calva and Lustig, 2010). Reduction of the fiscal deficit, the availability of currency, an expansion in the supply of education, and-in the case of

3 For an analysis of growth and inequality reduction in the first decade of the twenty-first century, see Gasparini and Lustig, 2011; Székely and Mendoza, 2015. For national official poverty rates (2003-15) see Annex, Figure A.8.3. 


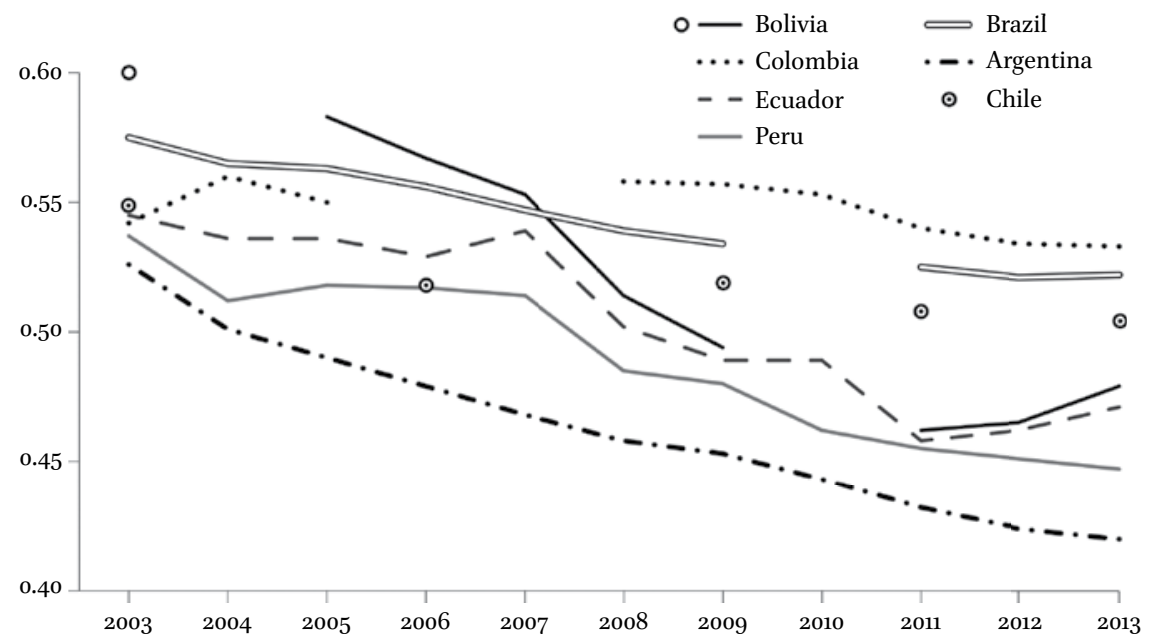

FIGURE 8.2 Evolution of income inequality (Gini), 2003-13. SOURCE: SEDLAC DATABASE.

countries involved in mining or oil - the distribution of royalties to local governments have undoubtedly had differentiated effects.

A decrease in the Gini coefficient (which expresses total inequality when equal to 1 and perfect equality when close to o) for total income has been widespread (Figure 8.2). In Brazil, Chile and Colombia inequality levels remain high and the decline has been less pronounced. Inversely, Argentina and Peru have posted ongoing decreases in income inequality throughout the period (Lustig et al., 2013a). Beyond these nuances, the convergence of trends means that growth, coupled with redistributive policies, has had a strong redistributive impact in both 'heterodox' and 'orthodox' countries. This fact encourages research to discover more about the implementation of universal social protection policies in various countries in the region.

In the context of the poverty and inequality reduction that transpired over the last decade, academics and international bodies have focused their attention on the expanding middle class, which is seen as platform for social cohesion and the consolidation of democracy. Growing internal markets, political stability, and demand for education, among other factors have allowed some emerging economies to escape the 'middle income trap'. Nevertheless, little is known about the real dimension of this expansion. In order to make an initial approximation, we present (Figure 8.3) the evolution of the polarisation posited by Foster and Wolfson (2010).

In general, the polarisation indexes in all of the countries diminish and converge to values between 0.40 and 0.45 . The exception is Colombia, which 


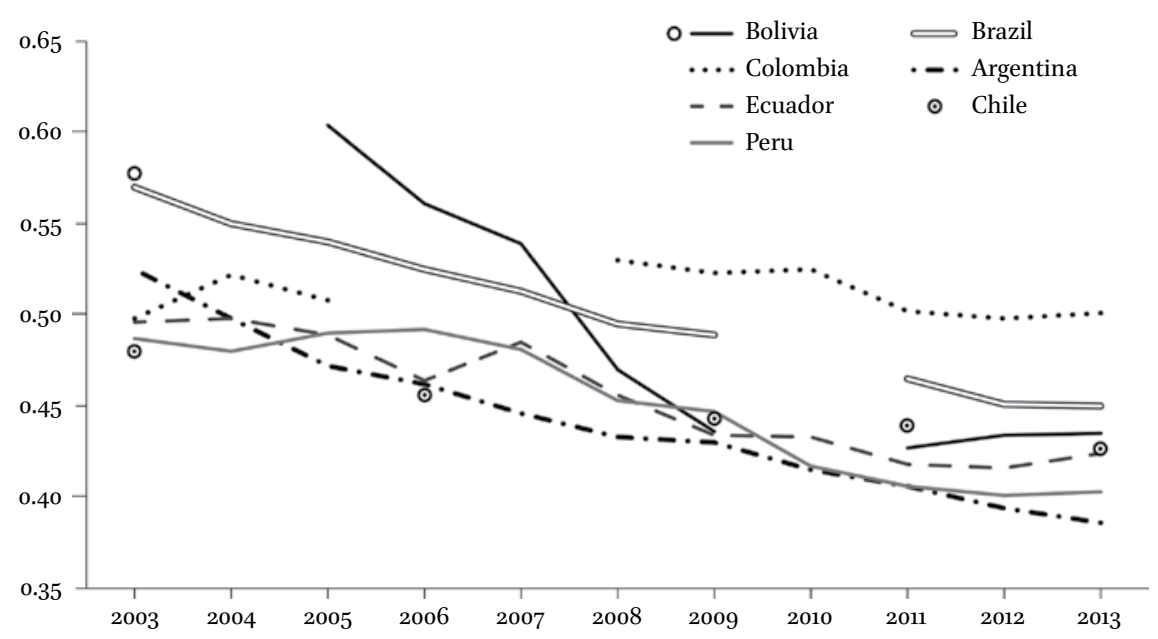

FIGURE 8.3 Evolution of income polarisation, 2003-13.

SOURCE: SEDLAC DATABASE.

showed no improvements in inequality or in the polarisation index. Brazil and Bolivia, which reported the highest levels of inequality and polarisation at the beginning of the decade of 2000, are also the countries that posted an increase in the population in the intermediate segments of distribution, which made them less polarised.

\section{The Drop in Poverty in the Most Recent Decade of Growth}

Peru has experienced one of the most significant drops in poverty in the region during the last decade (Figure 8.4). Between 2004 and 2014, during a period of strong and sustained macroeconomic growth, the incidence of poverty in the country fell 36 percentage points (a reduction of 61 per cent). The average poverty gap (the population mean of the relative distance of spending by the poor from the poverty line itself) also fell considerably, going from 22.1 per cent in 2004 to 5.8 per cent in 2014. Along the same lines, poverty severity, which measures heterogeneity in spending among the poor, also dropped significantly during the same period.

Figure 8.5 shows that the decrease in macroeconomic growth rates has been accompanied by a less significant decrease in poverty. Moreover, it is evident that the 'poverty elasticity' of growth in the period 2009-13 fell with respect to $2005^{-08}$ (the ratio of the relative variation in poverty to the relative variation 


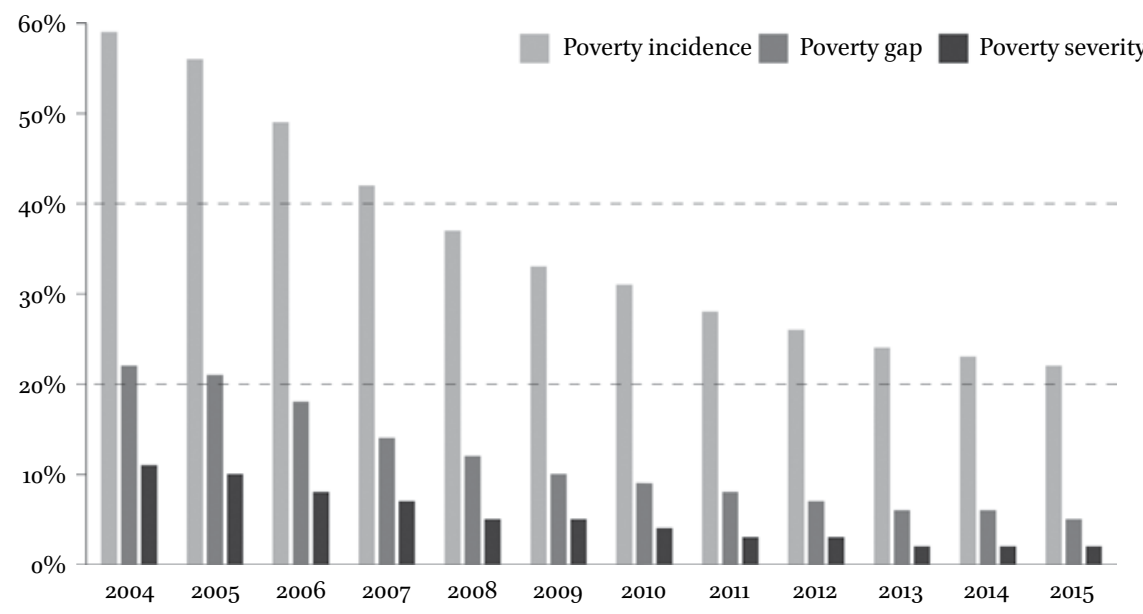

FIGURE 8.4 Poverty incidence, poverty gap and poverty severity (Peru). SOURCE: AUTHOR'S ESTIMATIONS BASED ON THE NATIONAL HOUSEHOLD SURVEY (ENAHO), 2004-15.

of the gross domestic product (GDP) dropped, on average, from 1.33 to 1.23). It is indeed surprising that the drop in the poverty rate during the short period of the recession of 2009 and during the downturn of 2013 was proportionally more significant that the variation in GDP. This, to a large extent, may be due to the fact that the drop and downturn in GDP was concentrated in the 'export and investment component', which affected the 'consumer' component in the mid and long terms rather than in the short run. Another possible explanation could lie in the growing importance of social programmes and of monetary transfers to the poor in particular. We should put to rest the widely held belief that a decrease in the pace of poverty reduction can be explained as follows: as poverty levels fall, it becomes more difficult for the remaining poor to exit poverty given that those who remain poor represent the hard core of the poorest among the poor. The poverty gap (mean solely among the poor) fell from 37.7 per cent in 2004 to 25.6 per cent in 2014, although it is also true that little variation was reported in the last five years (it fell only 3.5 percentage points). An examination of the urban/rural divide, where poverty gaps have been historically high, shows that the relative risk of poverty (both total and extreme poverty) increases more in rural households than in their urban counterparts. ${ }^{4}$

4 The odds ratio of rural households went from 1.42 to 2.03 and from 2.53 to 3.42 for total poverty and extreme poverty, respectively. 


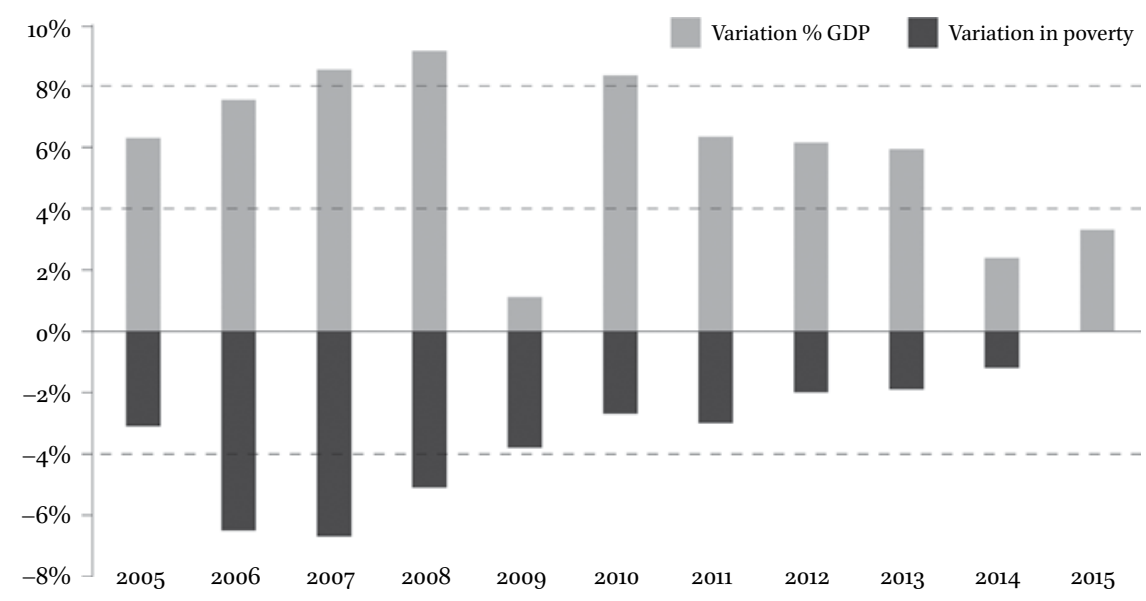

FIGURE 8.5 Evolution of GDP and the poverty rate, 2005-15. SOURCE: INEI.

Note: Percentage difference of GDP in constant PEN (soles 2007); variation in the incidence of total poverty in percentage points.

One of the arguments in favour of maintaining the primacy of the primaryexport model is that growth will eventually, like a tide that lifts all boats at the same pace, equally benefit the poorest households without the need for redistributive 'welfare' policies. Growth could be described as pro-poor when it favours the poor more than the non-poor, while neutral growth generates no bias either for or against the poor (homothetic growth of expenditure or income). On the other hand, growth can be termed anti-poor when household income or expenditure in the wealthiest segments grows more than those in the lower range of income distribution. Pro-poor growth reduces the gap between poor households and other households and can (although it does not necessarily) lead to a reduction in inequality as measured by the Gini coefficient.

Below (Box 8.1), we analyse the extent to which growth has been, or has not been, pro-poor by decomposing the variation in poverty into two parts: (1) variation due to 'pure' growth and (2) variation due to redistribution. It is important to note that redistribution can occur due to growth that is biased in favour of sectors that are intensive in terms of unskilled labour or if it is associated with a relative decline in the performance of higher education, transfers between households and public donations, among other factors.

The greater the gaps and the severity of poverty, the more difficult it will be to reduce poverty through neutral economic growth. In this way, inequality and poverty are intimately linked. 


\section{Box 8.1 Decomposition of poverty variations into the effects of growth and redistribution}

In the decomposition of poverty variations in terms of the growth effect and the redistribution effect, three distributions are compared: the distribution observed in $\mathrm{t}-1$, the simulated distribution that applies the average growth rate to all households, and the distribution observed in period t. The growth effect is the difference in the incidence of poverty divided by the simulated distribution and the distribution in t-1 (using expenditures at constant prices and the poverty line in $\mathrm{t}$ ). The distribution effect is the difference of poverty incidences between the distribution in $\mathrm{t}$ and the simulated distribution in t. (See Figure A.8.1 in the Annex for details of the non-parametric decomposition.)

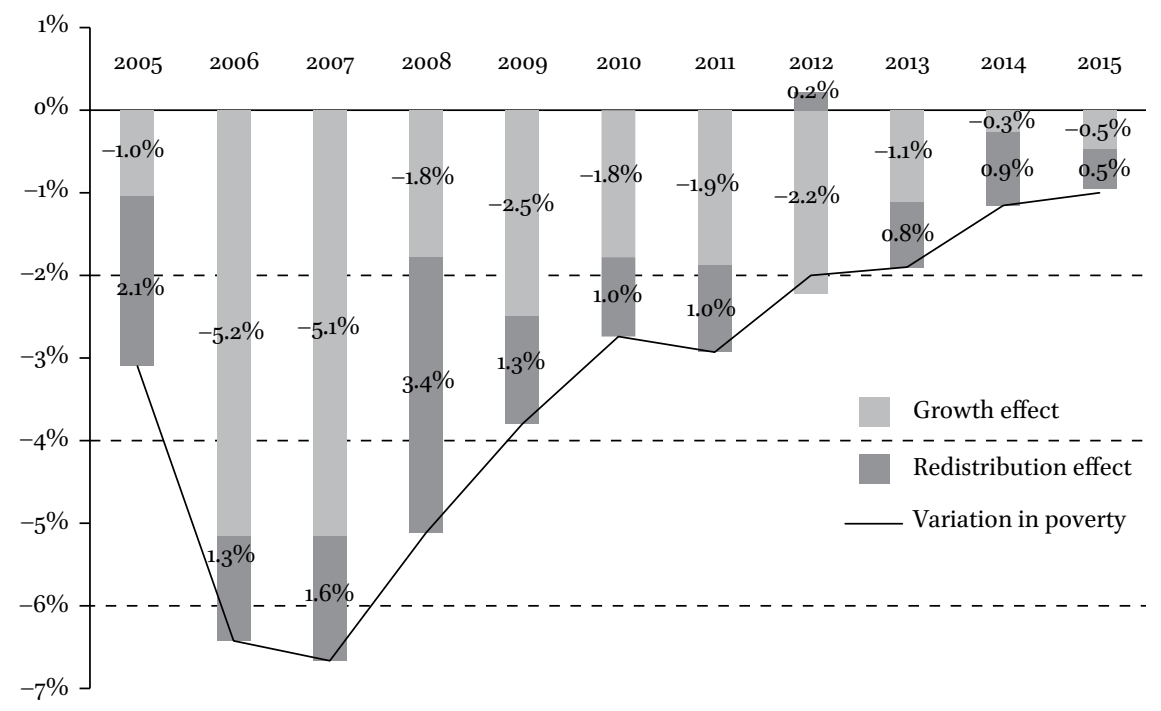

FIGURE 8.6 Decomposition of annual variations in poverty (in percentage). SOURCE: AUTHOR'S ESTIMATES BASED ON ENAHO, 2004-15.

Figure 8.6 presents, year by year, the growth and redistribution components of annual poverty changes and annual percentage point poverty variation. With the exception of the first year, the years that posted strong growth were relatively neutral in terms of distribution and on one occasion the result was slightly anti-poor (2012). The last three years of moderate growth were proportionally pro-poor. In 2015 , the reduction in poverty was due, primarily and for the second consecutive year, to the redistribution effect, which outpaced the growth effect. 
TABLE 8.1 Growth and redistribution components of poverty changes

\begin{tabular}{llllllll}
\hline & & $\begin{array}{l}\text { Incidence } \\
\text { of poverty }\end{array}$ & $\begin{array}{l}\text { Decrease in } \\
\text { the incidence } \\
\text { of poverty }\end{array}$ & $\begin{array}{l}\text { Growth } \\
\text { effect }\end{array}$ & $\begin{array}{l}\text { Redistribution \% Growth } \\
\text { effect Redistribution }\end{array}$ & & \\
\hline $2004-2006$ & 2004 & $58.7 \%$ & & & & \\
& & & & & & \\
& 2006 & $49.1 \%$ & -9.5 & 6.3 & 3.3 & $65.5 \%$ & $34.5 \%$ \\
\hline $2006-2011$ & 2006 & $49.1 \%$ & & & & & \\
& 2011 & $27.8 \%$ & -21.3 & -12.9 & -8.4 & $60.4 \%$ & $39.6 \%$ \\
\hline $2011-2015$ & 2011 & $27.8 \%$ & & & & & \\
& 2015 & $21.8 \%$ & -6.1 & -4.5 & 1.6 & $74.1 \%$ & $25.9 \%$ \\
\hline $2004-2015$ & 2004 & $58.7 \%$ & & & & & \\
& 2015 & $21.8 \%$ & -36.9 & 25.3 & 11.6 & $68.5 \%$ & $31.5 \%$ \\
\hline
\end{tabular}

SOURCE: AUTHOR'S ESTIMATES BASED ON ENAHO, 2004-15.

In the years 2004 to 2015 , the total variation in the incidence of poverty was 36.9 percentage points; the growth effect was 25.3 points and the distribution effect 11.6 points. Consequently, less than a third of the significant decrease in poverty was due to the redistributive component of growth, which, as we have already mentioned, includes not only the effect of social policy but also structural and situational changes in the economy. Growth driven by exports from the primary sector that is not accompanied by comparable development in production for the internal market, coupled with still moderate social expenditure, foreshadows a situation in which the decrease in poverty during the low growth period will be relatively modest. Additionally, the redistributive component of growth posted for the period 2011-15 accounted for only 25.9 per cent of the reduction in poverty (Table 8.1).

\section{Distributive Effects of Price Increases}

One of the channels through which macroeconomic factors affect the distribution of income is by way of the differentiated effects generated by absolute and relative price variations. Price increases primarily affect those who are not able to index their income, while changes in relative prices can lead to a larger loss of buying power in the poorest homes if said variation is stronger in terms of food than non-food items. In the case of Peru and other developing countries, 
the effects also depend on whether or not households are net producers or consumers, in this case, of food.

In 2004-15, the general price level (measured through the Consumer Price Index-CPIo) increased by an average annual rate of 3.9 per cent with a peak of 7.6 per cent during the 2008 crisis (meaning an accumulated increase of 43.1 per cent between 2004 and 2015). Total poverty and extreme poverty lines increased in similar proportions (from 42.9 per cent and 58.5 per cent, respectively). The food price index increased by an average rate of 5.3 per cent. To what extent did these variations affected inequality and poverty?

In the calculation of these effects, we must consider, on one hand, the fact that consumption structures differ according to spending levels and, on the other, the spatial difference in price levels. As such, the deflation of nominal expenditure considers the specific weighting of the different groups of expenditure per household. In terms of the disparities of price levels, we deflated expenditure with the spatial deflator of multilateral prices calculated by the Peruvian National Institute of Statistics (Instituto Nacional de Estadistica e Informatica: INEI). Figure 8.7 shows the differences between the evolution of nominal expenditure and of real expenditure for each of the expenditure deciles between 2004 and 2015. It is evident that losses due to inflation were higher for the poorest deciles while the richest deciles suffered no losses due to inflation.

This differentiated effect of inflation by decile is also correlated with poverty reduction. The incidence of poverty is found by comparing the nominal expenditure of the current year with the poverty line of the previous year

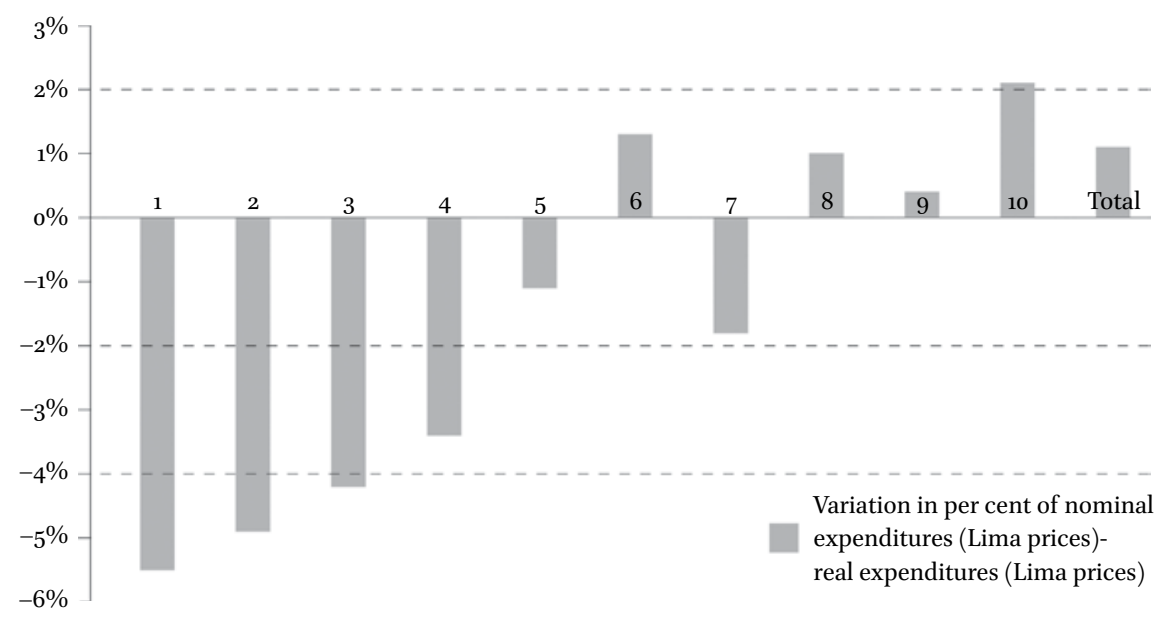

FIGURE 8.7 Changes in expenditure levels due to inflation by deciles, 2004-15. SOURCE: AUTHOR'S ESTIMATES BASED ON ENAHO, 2004-15. 


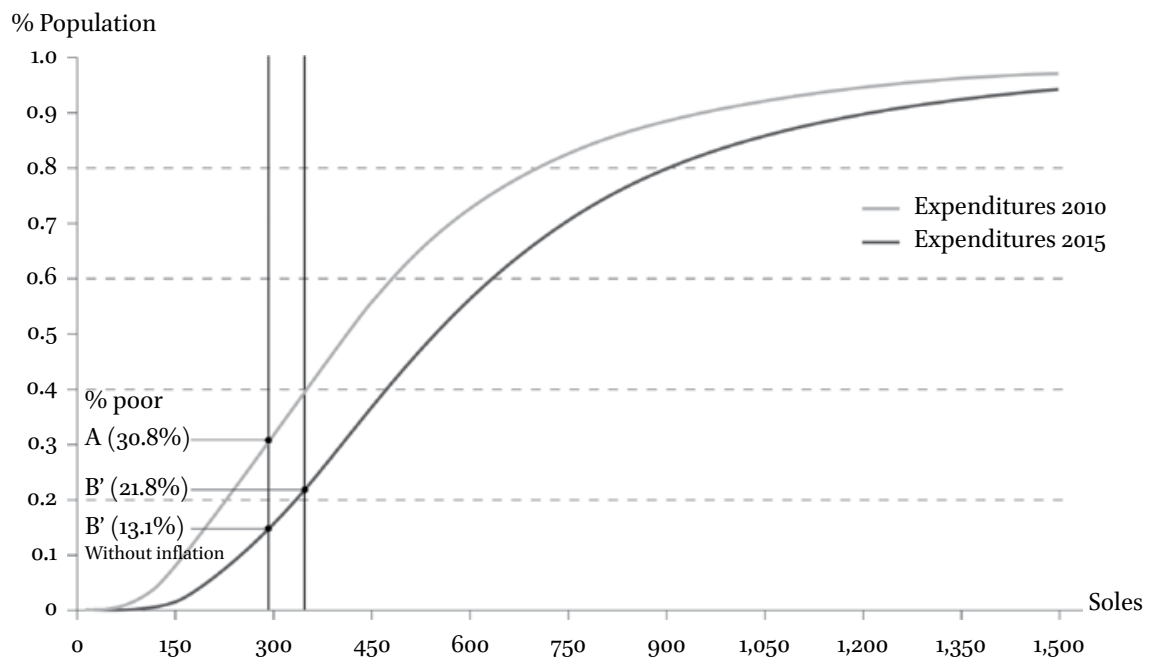

FIGURE 8.8 Direct effect of inflation on poverty reduction.

SOURCE: AUTHOR'S ESTIMATES BASED ON ENAHO, 2010 AND 2015.

Notes: If there had been no inflation in $2010-15$, the poverty line in 2015 would have been the same as in $2010\left(=B^{\prime}=13.1 \%\right)$.

Observed variation of poverty $(30.8 \%-21.8 \%) \mathrm{B}-\mathrm{A}=-9$ points.

Without inflation, poverty would have fallen from $\mathrm{B}^{\prime}-\mathrm{A}=-17.7$ points $=$ (30.8\%-13.1\%).

The effect of inflation is equal to: $\left(\mathrm{A}^{-} \mathrm{B}^{\prime}\right)-(\mathrm{A}-\mathrm{B})=\left(\mathrm{B}^{\prime}-\mathrm{B}\right)-8.7$ points $=$ (21.8\%-13.1\%).

considering the current year's prices. The direct effect of the increase in prices is, as such, the difference between the incidence using the line at last year's prices and the nominal expenditures of the current period with regard to the variation of the incidence with lines at prices that have been indexed to inflation (Figure 8.8). If we look at the period 2010-15, poverty fell by 9 points but if no inflation had been in play, the reduction would have been 17.7 points. The net effect is that inflation has offset the drop in poverty by 8.7 points (or 11.6 points if we consider the period 2004-15).

\section{$6 \quad$ Vulnerability of Households}

The decrease in poverty observed over the last decade, measured through static indicators (of incidence, gap and severity), does not reveal the dynamic of poverty, particularly in terms of the incoming and outgoing flows of poverty. The same poverty rate is compatible with very different sizes of flows of population that enter and exit poverty - which would, in this case, give the same net balance. It is important to note that economic insecurity and vulnerability 
to poverty (measured as a risk of falling into poverty) should be considered dimensions of well-being.

To approximate the measurement of vulnerability, we consider the individual trajectories of households using longitudinal data (household panel) and identify, for two successive periods, the proportion of households that remain in poverty, those that fall into poverty, those that exit poverty and those that have never been poor.

Figure 8.9 shows that the reduction in poverty measured was due primarily to a decrease in the number of households that have always been poor while the proportion of vulnerable households remains practically constant, at around 10 per cent of total households.

Seen from another angle, we can consider the population that has not been poor every year, but which experienced at least one episode of poverty of at least one year during the period, as part of the vulnerable population. The Peruvian National Household Survey (Encuesta Nacional de Hogares, ENAHO) uses a subsample panel that follows the same households every year. Table 8.2 shows the results of the household panel (2007-11). Slightly more than one household out of ten (12.4 per cent) was poor in each and every one of the five years considered while a little less than half ( 47.2 per cent) experienced no episodes of poverty in the period 2007-11. The most surprising result is the

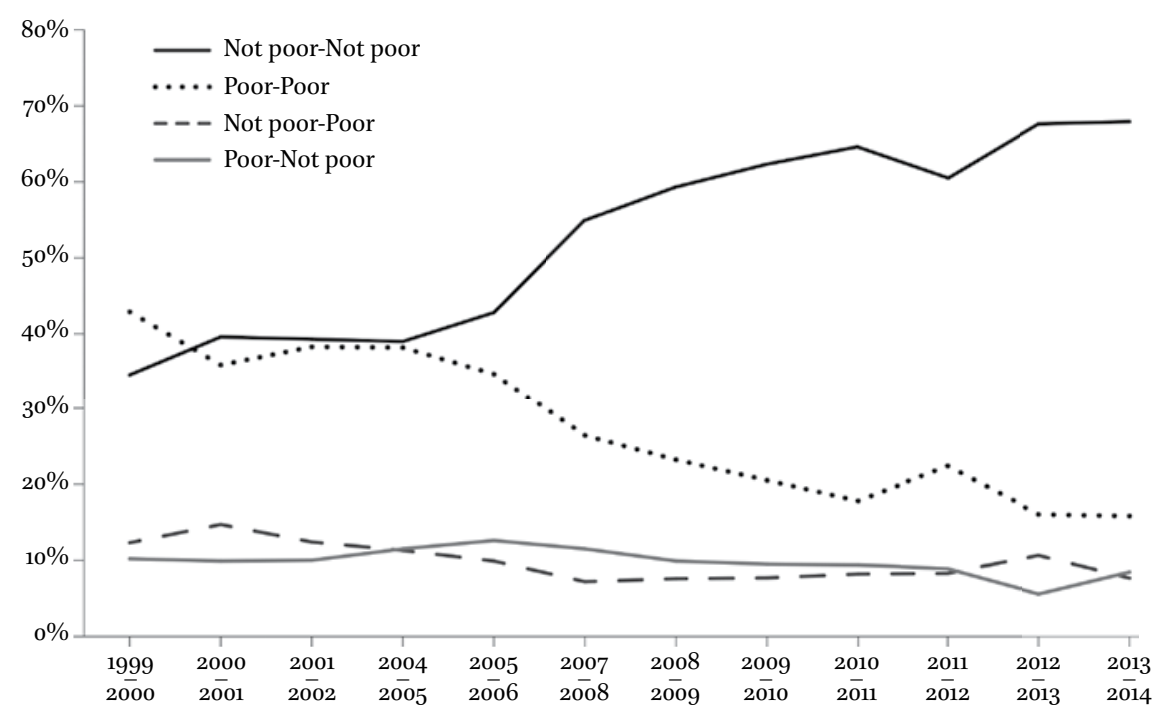

FIGURE 8.9 Poverty transitions, 1999-2014.

SOURCE: AUTHOR'S ESTIMATES BASED ON ENAHO, 1997-2014.

Note: The period considered covers distinct designs of the total sample and the panel. 


\begin{tabular}{|c|c|c|c|c|}
\hline \multirow[b]{2}{*}{$\begin{array}{l}\text { Episodes of poverty } \\
2007-11\end{array}$} & \multicolumn{3}{|c|}{ Poverty in 2011} & \multirow[b]{2}{*}{ Households } \\
\hline & Non-poor & Poor & Total & \\
\hline o & 47.2 & 0.0 & $47 \cdot 2$ & $4,237,301$ \\
\hline 1 & 10.9 & 2.1 & 13.0 & $1,167,393$ \\
\hline 2 & $7 \cdot 3$ & 2.6 & $9 \cdot 9$ & 886,717 \\
\hline 3 & $5 \cdot 2$ & $3 \cdot 9$ & 9.2 & 823,325 \\
\hline 4 & $3 \cdot 5$ & 4.8 & 8.4 & $75^{1,394}$ \\
\hline 5 & 0.0 & 12.4 & 12.4 & $1,113,331$ \\
\hline Total & 74.1 & $25 \cdot 9$ & 100 & $8,979,461$ \\
\hline
\end{tabular}

SOURCE: AUTHOR'S ESTIMATES BASED ON ENAHO, 2007-11.

very high proportion of the population living in households that are vulnerable to poverty (transitory poor), given that four out of ten experienced at least one episode of poverty. This proportion contrasts strongly with the proportion of poor in 2011, the last year of the period. In other words, in 2011, the poverty 'halo' comprised 66.3 per cent of the population and not only the 25.9 per cent that lived in poverty in that year.

\section{$7 \quad$ Social Programmes and Poverty Reduction}

We have seen that part of the reduction in poverty is due to growth that is moderately pro-poor. In this section, we will examine the extent to which targeted public transfers explain this pro-poor bias in growth. To accomplish this, we will examine different components of real expenditure based on forms of acquisition. Total expenditure includes both purchases and goods and services acquired through self-consumption, self-supply, in-kind payments, transfers from other households and public transfers. We will focus primarily on the last component, public transfers.

Public transfers include different transfer programmes (for example, the programmes Juntos, Pension 65, Beca 18, etc.) that have a direct impact (through the transfer amount) and an indirect impact (through induced behaviours) on the well-being of households. 
In 2014, public transfers represented 3.4 per cent of average total household expenditure; this percentage does not differ significantly from one year to the next (minimum variations, limited within the range of 3.1 per cent to 3.6 per cent). The 'efforts' made by the various governments in the fight against poverty has not led them to allot larger transfer amounts to households in proportion to average household expenditure. Given that these are targeted transfer programmes, we should examine the relative importance of these public transfers in different segments of expenditure distribution. Figure 8.10 also presents these proportions for the five poorest deciles and for the national average. For decile 1, the poorest, public transfers reached a peak in 2006 (11.8 per cent of total expenditure) and fell during three successive years to 7.2 per cent in 2009. Transfers then rebounded in 2010 only to fall again in 2012; growth reported in the final two years brought the transfer amount back to levels comparable to those seen in 2007 (8.4 per cent of total expenditure in 2014). The profile of the evolution observed for the second and third poorest deciles is very similar to that of the five poorest deciles but the proportion of public transfers represents an average of 2.2 and 3.6 percentage points less, respectively. In the period 2004-14, public transfers represented, on average, 8.5 per cent of the expenditure of the extremely poor. These proportions remained relatively stable over that decade.

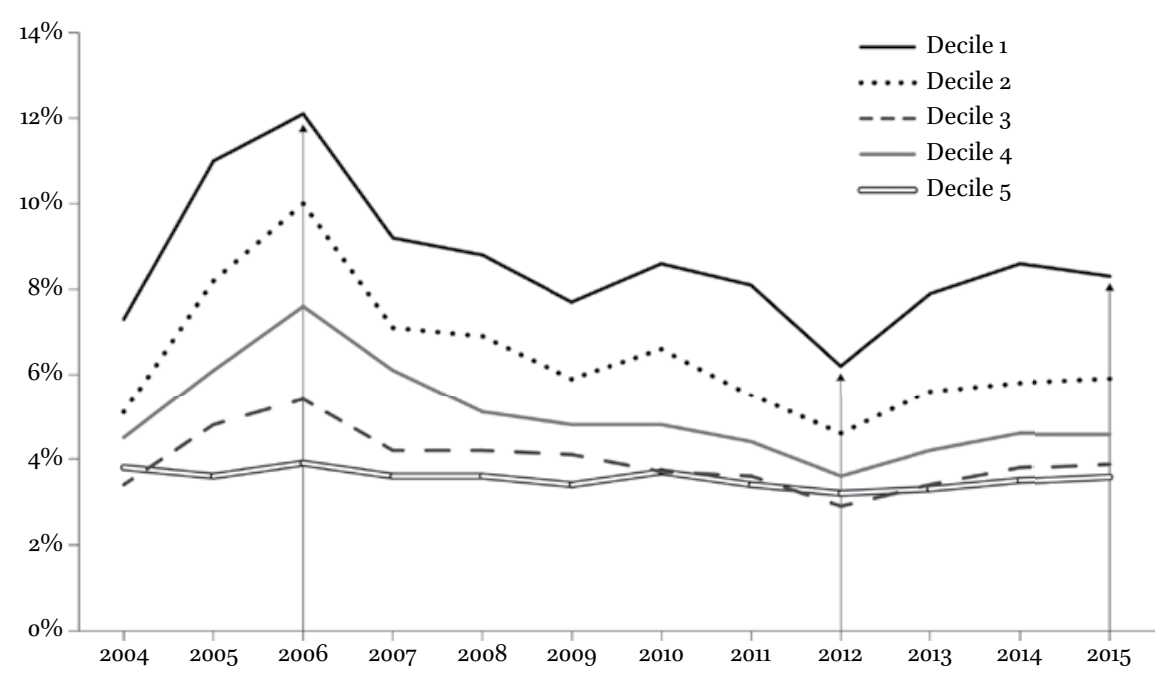

FIGURE 8.10 Relative importance of public transfers by deciles, 2004-15. SOURCE: AUTHOR'S ESTIMATES BASED ON ENAHO, 2004-15. 


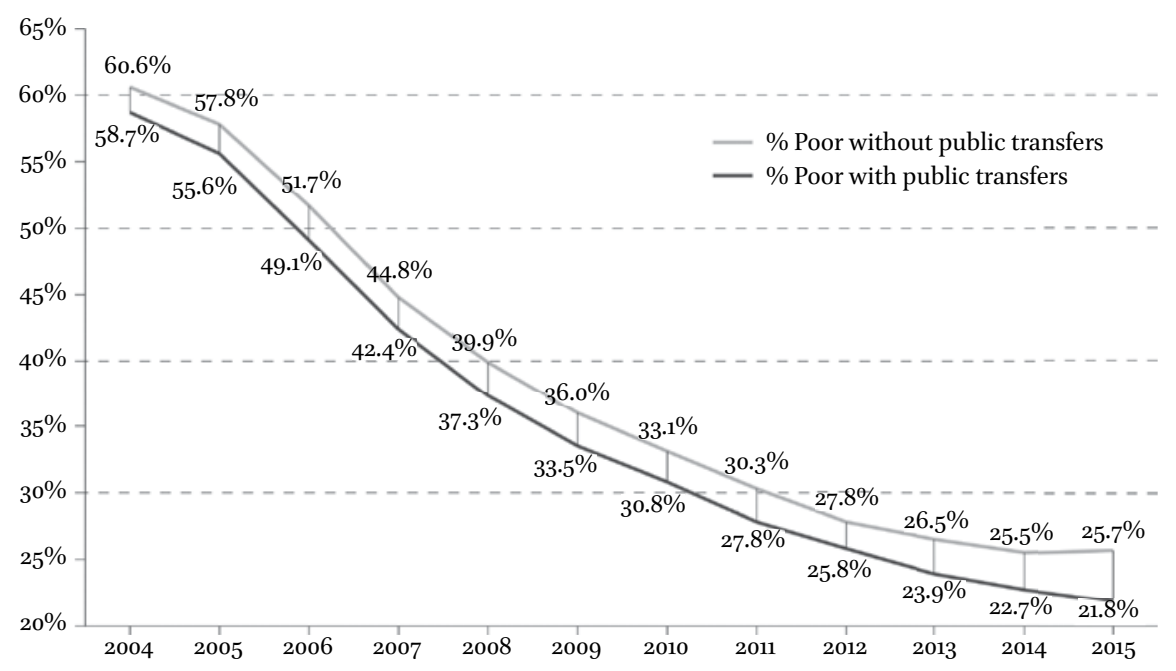

FIGURE 8.11 Direct impact of public transfers on the incidence of poverty.

SOURCE: AUTHOR'S ESTIMATES BASED ON ENAHO, 2004-15.

What would the poverty level have been without public transfers? If we consider only the direct impact of such transfers, in Figure 8.11 we see that the impact would have increased over time. In 2004, the absence of transfers would have increased poverty by 1.9 supplementary points while in 2014 poverty would have increased by 3.9 points. Two sub-periods can be identified: the first comprises the years 2004-08, during which the absence of public transfers would have meant a 2.6 point increase in the incidence of poverty, which is lower than the amount found in the second period, which encompasses the years 2009-14 (1.3 points of supplementary poverty.)

What amount would the non-poor have to transfer, as a proportion of their total household expenditure, to allow poor households to cover the cost of a basic food basket? This would give us an idea of the dimensions that policies with regard to taxation and to transfers to households must contemplate in order to eradicate poverty.

It is important to note that the strong reduction in poverty was accompanied by a drop in the amount associated with the redistributive effort over the course of the period examined. Although 'eliminating' total poverty would have involved, in 2004, mobilising the equivalent of about 24 per cent of the expenditure of non-poor households, in 2015 this percentage fell to only 3 per cent (Figure 8.12). If the objective were more modest and consisted solely of eliminating extreme poverty rather than total poverty (extreme and non-extreme), then the redistributive effort would have represented about 


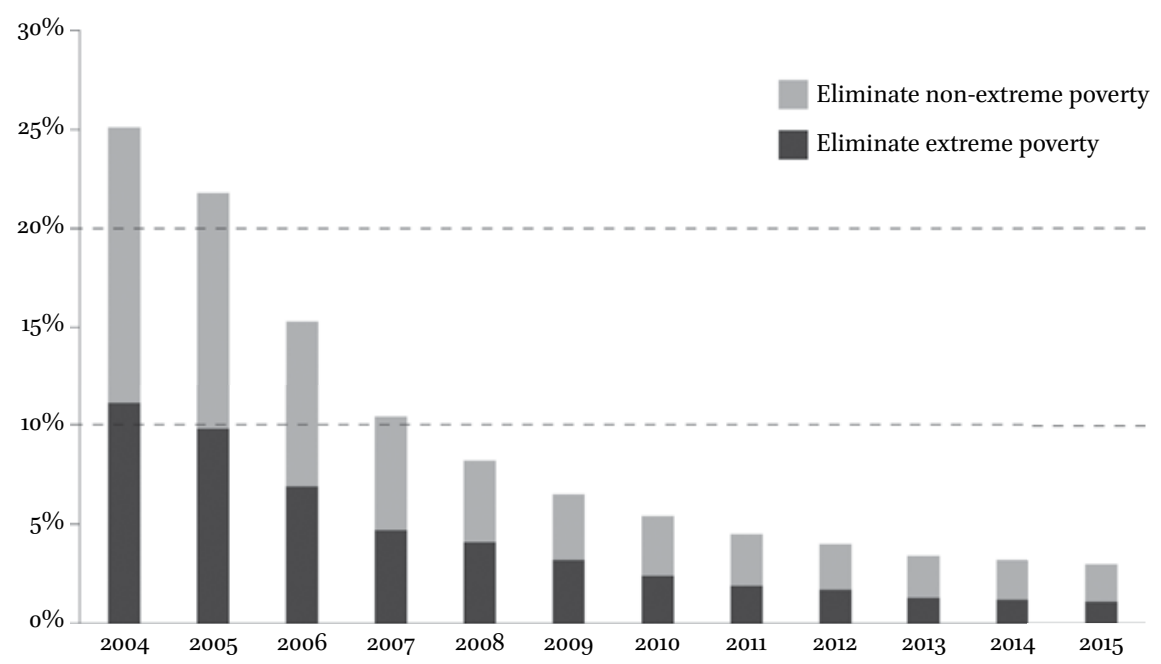

FIGURE 8.12 Per cent of total expenditure of non-poor households needed to eliminate the poverty gap.

SOURCE: AUTHOR'S ESTIMATES BASED ON ENAHO, 2004-15.

10 per cent of the expenditure of the non-poor in 2004 and only 1 per cent in 2015. In other words, given fiscal reserves and the fact that fiscal pressure is low in Peru (around 16 per cent) in comparison to countries with comparable GDP levels, suppressing poverty through transfers to poor households is an attainable goal.

\section{The Evolution of Inequality}

The levels of income inequality, measured with the Gini coefficient, are relatively high and show a slight downward trend beginning in 2008 (Figure 8.13). The same trend is observed in the case of real per capita expenditure inequality. The income Gini coefficients fluctuate between 0.51 and 0.44 and those relative to expenditure, between 0.41 and 0.35 (Annex, Figure A.8.2).

Despite the important gaps in income and expenditures between households in urban and rural areas, the levels of inequality within each of these ambits are high and very similar.

Another way of examining changes in inequality is by comparing the relative shares of total expenditure of each of the quintiles of distribution for two different periods (Figure 8.14). If we consider total expenditure and its distribution in quintiles, in 2004 and 2015 we can see that the decrease in 


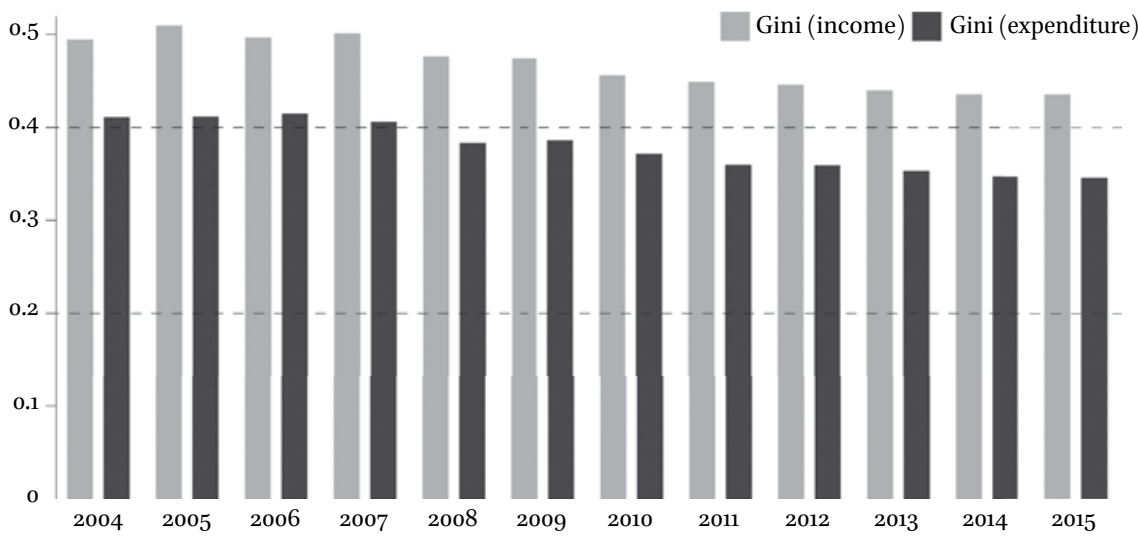

FIGURE 8.13 Evolution of the inequality of household income and expenditure, 2004-15. SOURCE: AUTHOR'S ESTIMATES BASED ON ENAHO, 2004-15.
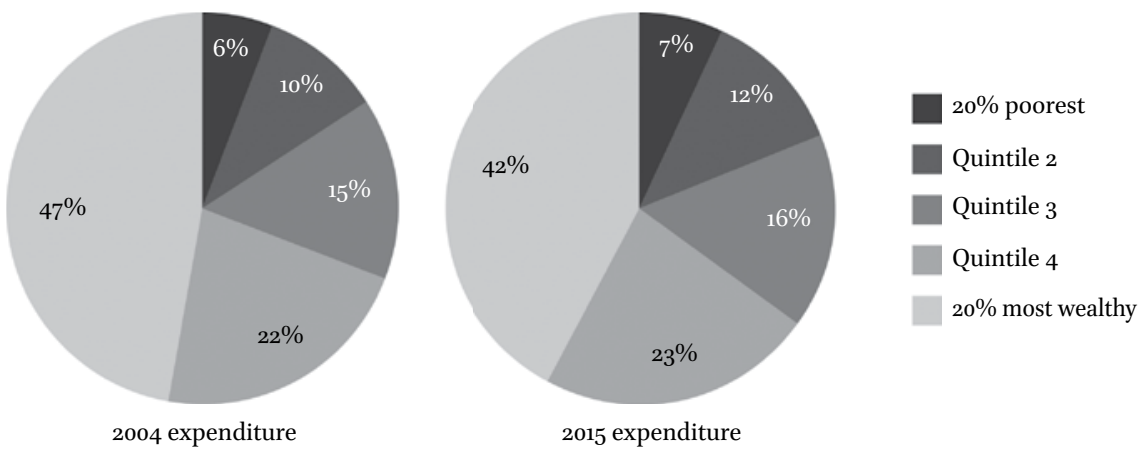

FIGURE 8.14 Distribution of expenditure by quintiles, 2004 and 2015.

SOURCE: AUTHOR'S ESTIMATES BASED ON ENAHO, 2004 AND 2015.

inequality led to the fifth richest quintile losing 5 percentage points, redistributing one percentage point to each of the remaining quintiles with the exception of the second poorest quintile, which received two percentage points of expenditure.

The ratio of average expenditures for the richest quintile to those of the poorest quintile reached a peak in 2007 and declined progressively and regularly until 2011. From that point on, gap reduction is basically imperceptible. There are no significant changes in other portions of the distribution if we compare the ratios of the $75^{\text {th }}$ percentile with those of the $25^{\text {th }}$ and $5^{\text {oth }}$ percentiles given that these percentiles remain basically constant throughout 2004-15. 
The level and evolution of inequality, as measured by the Gini coefficient, tell us little about expansion or the lack thereof in the middle segments' share of total income (often considered as equivalent to the expansion of the middle class) or if, on the contrary, we are facing a growing polarisation in income. Polarisation can lead to a loss of social cohesion and to higher levels of social conflict whereas the expansion of the middle class drives more citizen participation to monitor the political class and public policies.

To measure polarisation, we will use the index proposed by Wolfson, which is directly related to the Gini index. The Gini index measures the area between the diagonal and the curve of Lorenz in relation to the lower area of the diagonal; the polarisation index examines the relative importance of both extremes of the distribution (Figure 8.15).

Our estimates for the polarisation index for both income and real per capita expenditures show a downward trend, which is more pronounced in the case of income than in that of expenditures (Figure 8.16). We cannot discard the possibility that there is an underestimation of the degree of inequality that stems from the fact that it is difficult for surveys to capture certain sources of income in the richest households. Rejection rates (unwillingness to participate in surveys), under-declaring and sampling problems also impede an acceptable estimate of very high income. Comparing income aggregates estimated by national accounts and by household surveys has led several authors to attempt to correct the Gini coefficients. Nevertheless, very often the hypotheses made concerning the distribution of discrepancies are, by direct consequence, responsible for the observed results although there is no way of corroborating

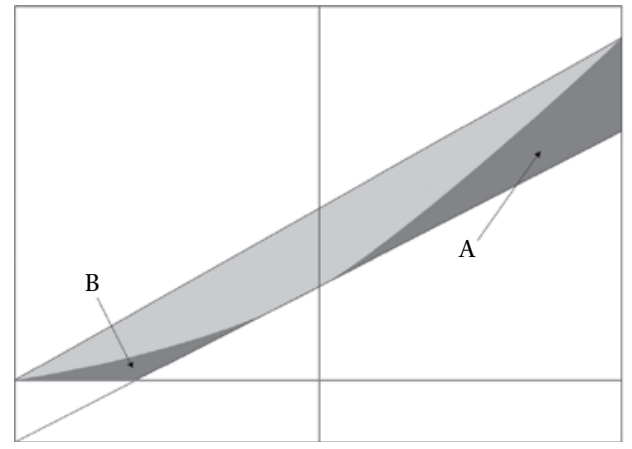

The area shown by $\mathrm{A}+\mathrm{B}$ indicates the degree of polarisation. Foster and Wolfson (2010) derive the following formula to calculate this area: $\mathbf{P}=\mathbf{2}(\mathbf{2 T}-\mathrm{Gini}) / \mathrm{mtan}$

mtan $=$ the median tangent $=$ median/average $\mathrm{T}=0.5-\mathrm{L}(0.5)$, which is the difference between $50 \%$ and the proportion of expenditures of the other half of households.

FIGURE 8.15

Inequality and polarisation: a graphical representation. SOURCE: FOSTER AND WOLFSON (2010, 264). 


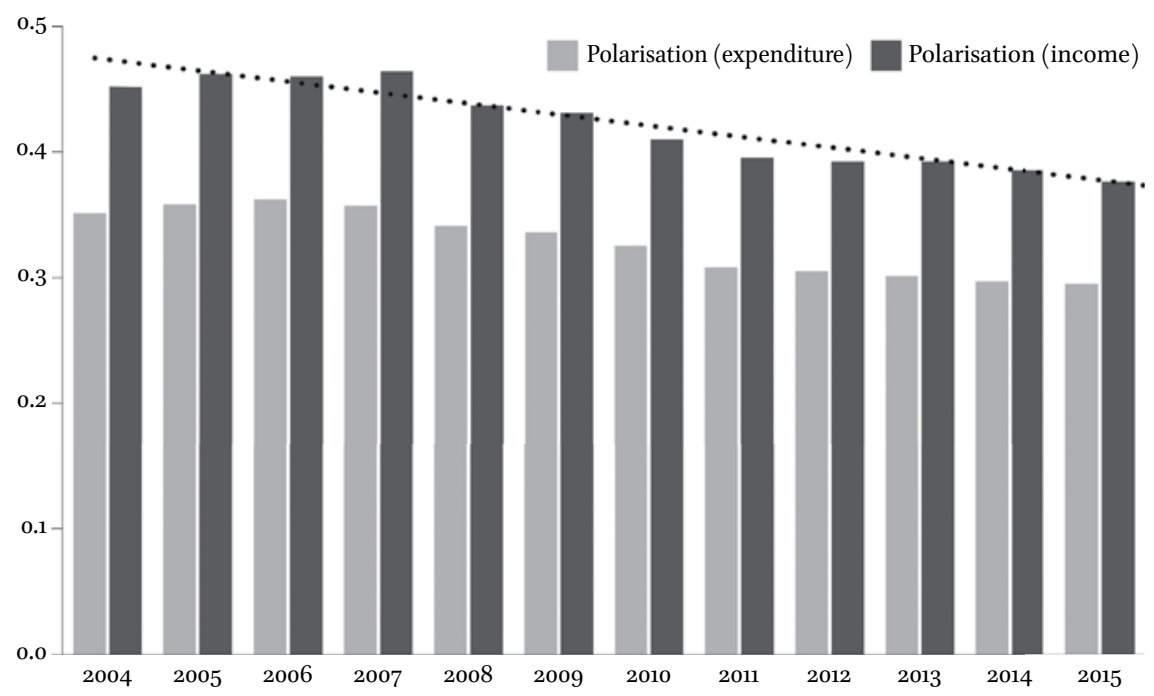

FIGURE 8.16 Evolution of the polarisation of income and household expenditure. SOURCE: AUTHOR'S ESTIMATES BASED ON ENAHO SURVEYS, 2004-15.

these hypotheses. Combining the information from household surveys with tax records is a promising but still pending task in Peru.

10

\section{The Contributions of the Job Market and Social Policies to Variations in Poverty and Inequality: A Shapley Decomposition}

A reduction in poverty or in inequality may be associated with the behaviour of labour income, remittances or private transfers, extraordinary income or even public transfers through different social programmes. As seen earlier in this chapter, despite differences in political orientations, the countries in the region experienced a strong reduction in poverty and inequality. It is valid to question if this reduction was achieved through the same channels: the market, for those with policies inspired by the Washington Consensus, or public transfers, in the case of countries with heterodox policies.

In an attempt to answer this question, we will use the decomposition method proposed initially by Barros et al. (2006) and subsequently applied by Kakwani et al. (2009) in Brazil and the approach used to analyse Chile, Brazil and Mexico proposed by Zepeda et al. (2009), and later extended by Azevedo et al. (2013a). This method is based on the additive nature of different components of income and on the construction of a counterfactual distribution 
that removes one component of income at a time and then recalculates the indicators to identify their contribution to changes in poverty and inequality. The algorithm developed by Azevedo et al. (2012) resolves issues regarding the sensitivity of results to the order in which each component of income is considered. To avoid this problem, all possible combinations are calculated and the average of their respective contributions is used as a measure of its contribution (Azevedo et al., 2012).

In Figure 8.17, each quadrant represents the relative contribution of each income component (grouped into five main categories) to variations in poverty and inequality between 2004 and 2015. The importance of public transfers, which mainly correspond to diverse social programmes, is particularly noteworthy in that they account for 16 per cent and 26 per cent of the reduction in the incidence of poverty and of the poverty gap, respectively. These transfers have also played a significant role in the observed reduction in inequalities, contributing 40 per cent to the observed drop in the Gini coefficient.

The contrast between the 2004-10 period and that of 2010-15 reveals an important shift in the sources of changes in poverty and inequality. On the one hand, the contribution of labour income to poverty reduction fell (from 80 per cent to $5^{2}$ per cent). This was, without a doubt, linked to the downturn and in some cases to a recession in productive activities for the internal market, activities that absorb the majority of qualified workers. On the other hand, this significantly increased the contribution of public transfers to both poverty

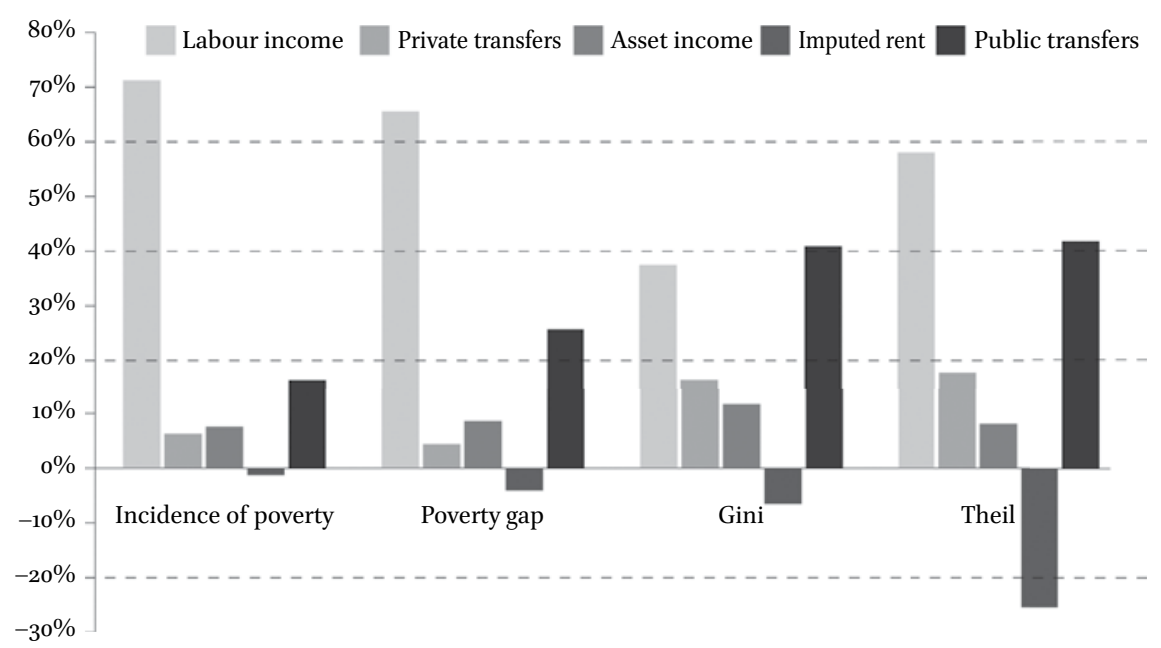

FIGURE 8.17 Decomposition of the variations in poverty and inequality between 2004 and 2015, according to household income components.

SOURCE: AUTHOR'S ESTIMATES BASED ON ENAHO SURVEYS, 2004-15. 
reduction and inequality reduction (see Table A-1 in the Annex). In the period 2004-10, transfers accounted for only one-third of the reduction in inequality (Gini), while in $2010-15$ this same component represented half of the reduction in inequality.

A similar exercise, conducted by Azevedo et al. (2013b) for 14 Latin American countries for the period 2000-10, allows us to compare the case of countries with orthodox policies with that of those countries that opted not to change the patterns of growth based on primary exports and prudent approaches to fiscal and monetary policy management. This also matches the analyses by country presented by Lopez-Calva and Lustig (2010). Nevertheless, the relative contribution of pensions, non-labour income, and changes in the workforce in households compared to changes in inequality differs among countries. In countries with more highly developed institutions and better living conditions (Argentina, Brazil and Chile and to a lesser extent Colombia), income from pensions and transfers plays a more important role than it does in other countries. Peru and Ecuador share similar characteristics in terms of the preponderance of the contribution of labour income. Peru is unique in that it is the only country in the study that registers a negative contribution (which increases inequality) for non-labour income (-14 per cent). This result matches our estimates (a negative contribution of -11 per cent to Gini and -19 per cent to the Theil index, Table A-1). Our estimates for the most recent period (2010-15) show that this contribution ceases to be significant in the case of Gini but remains negative in the Theil case.

11

\section{The Perception of Inequality and the Role of the State in Redistribution}

The consequences of higher or lower degrees of economic inequality and social pressure that seeks to drive redistributive policies depend on the population's perception of distributive justice, a preference for more income equality, the factors that have an impact on disparities in quality of life, and what role is devoted to the state with regard to reducing inequalities. To explore these issues, we analyse the Latinobarómetro opinion surveys and the World Values Surveys, which help us situate Peru's case in the Latin American context (Figure 8.18).

A persistent and surprising fact is that a high percentage of the population of Peru perceives the inequality level to be very unjust. In fact, this figure exceeds those posted by countries whose inequality levels (measured by the Gini index) are actually higher. Panama, Ecuador, Bolivia and the Dominican 


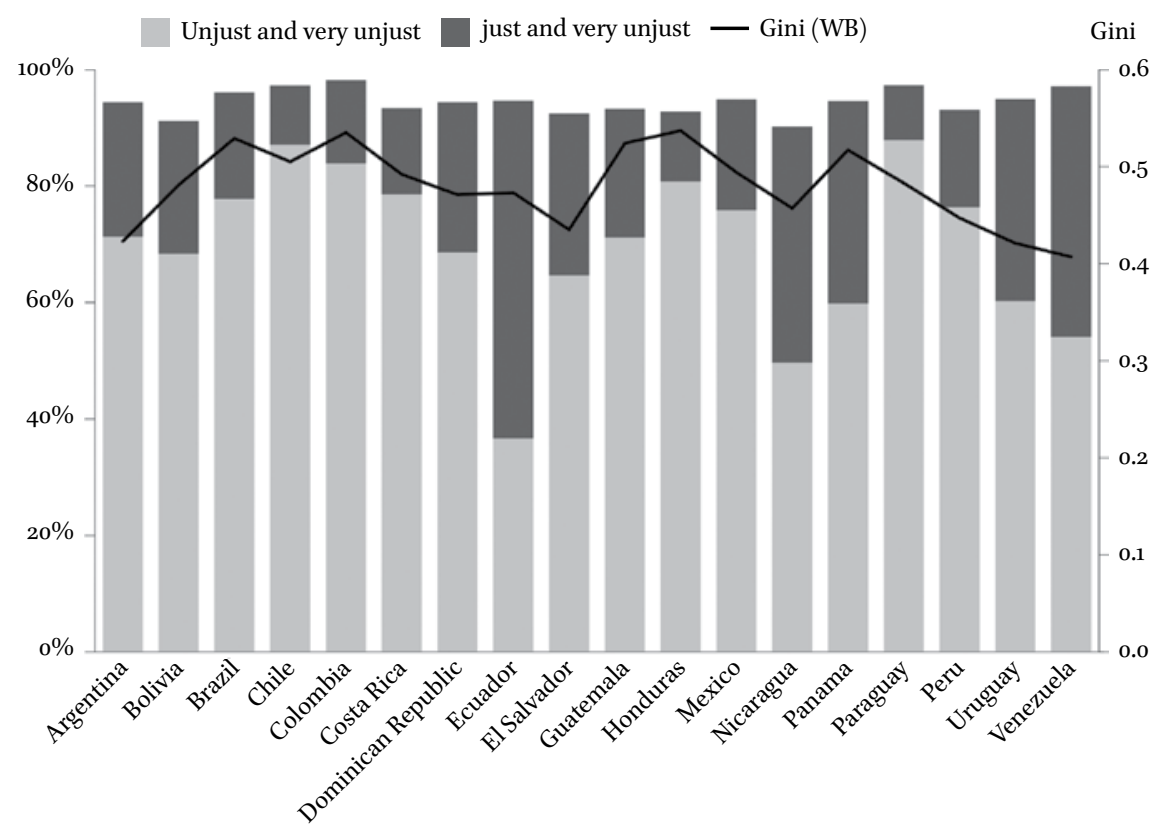

FIGURE 8.18 Perception of distributive justice and the inequality index, 2013. SOURCES: AUTHOR'S ESTIMATES BASED ON LATINOBARÓMETRO, 2013; GINI COEFFICIENT-WORLD BANK.

Republic have levels of inequality that are higher than those in Peru. Nevertheless, a smaller proportion of the population of these countries is of the opinion that such a distribution is unfair or very unfair. In Peru, the origin of inequalities is considered, to a certain extent, less 'legitimate' than in some of the other countries in the region that have comparable or higher levels of inequality.

An analysis of the nine latest Latinobarómetro surveys sheds light on how perceptions of distributive justice evolved over time during the period of economic growth (Figure 8.19). In the period of crisis (1997-2001), the percentage of the population that considered distribution fair or very fair was just 5.2 per cent. In the initial phase of expansion, this proportion fluctuated between 8.4 per cent and 12.8 per cent. Tolerance of inequality seems to have increased moderately during the last five-year period, when the proportion of the population that believed that distributive justice was fair or very fair was equivalent to 16.5 per cent of the total.

The perception that the distribution is unfair or very unfair does not mean, in a mechanical sense, that the population believes that incomes should be levelled. The World Values Survey did not reveal that the population adhered consistently over time to a meritocratic conception of distribution that in 


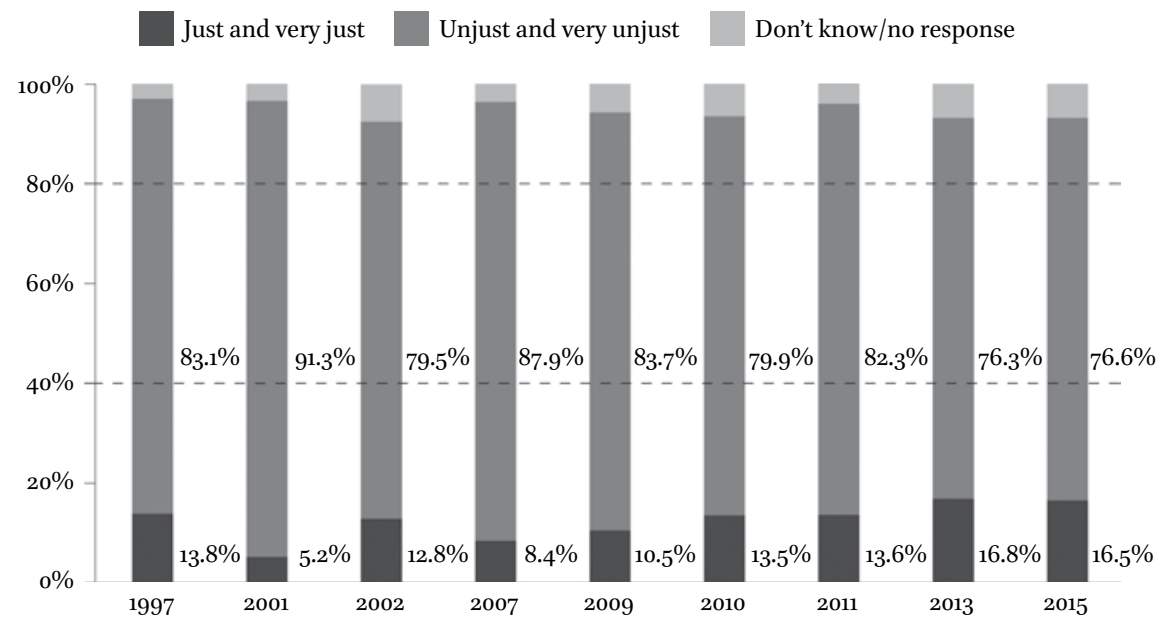

FIGURE 8.19 Evolution of the perception of distributive justice, 1997-2015 (Peru). SOURCE: AUTHOR'S ESTIMATES BASED ON LATINOBARÓMETRO DATA, 1997-2015.

general posits that he or she who tries harder should be paid more. Distributive injustice could be more related to the obstacles (discrimination, inequality of opportunities and inequality of wealth) that generate a scenario in which the rules of the game are not the same for all. A plausible explanation of the preference for a meritocratic conception of distribution is linked to the very high percentage of independent, informal workers in the country, who-as their own 'bosses' - have an income that is not part of a salary mediation scheme and instead comes directly from the market, which rewards greater or lesser effort. This may lead some to lose sight of the fact that these individuals compete with other informal workers to obtain a 'piece of the pie', since the demand for their products/services does not change with alterations in the number of informal workers. In sectors with low entry costs, it will be necessary to spend more hours working in order to maintain income levels. The absence of a potentially conflictual capital/work relationship means that the relations of subordination in which independent workers are embedded-independent workers who profess that they are in favour of meritocratic rules for income generation-remain invisible.

A comparison of countries in the region that have a lower proportion of independent workers than Peru demonstrates even more clearly the specificity of meritocratic and non-redistributive preferences for income equality. This meritocratic conception was found in less than half of the opinions registered in Argentina, Brazil, Chile, Colombia and Uruguay, while in Peru approximately 8 out of 10 adhere to this belief (Table 8.3). 
TABLE 8.3 Preferences in the region for more income equality (in percentage)

Argentina Brazil Chile Colombia Peru Uruguay

\begin{tabular}{lcrrrrr}
\hline $\begin{array}{l}\text { Income should be } \\
\text { more equal(1 to 5) }\end{array}$ & 53.6 & 49.1 & 61.4 & 52.4 & $\mathbf{2 1 . 1}$ & 52.9 \\
$\begin{array}{l}\text { He or she who works } \\
\text { harder should be } \\
\text { paid more (6 to 10) }\end{array}$ & 46.4 & 50.9 & 38.6 & 47.6 & 78.9 & 47.1 \\
$\begin{array}{l}\text { Total } \\
100\end{array}$ & 100 & 100 & 100 & 100 & 100 \\
\hline
\end{tabular}

SOURCE: AUTHOR'S ESTIMATES BASED ON THE WORLD VALUES SURVEY-1996, 2001 AND 2008.

The preponderant idea that wealth is expandable, and can increase in a way that is sufficient for all, runs counter to the idea that wealth is fixed and only a few will enrich themselves at the expense of others, and is consistent with the meritocratic conception of income distribution. At the same time, not seeing wealth as fixed attenuates potential distributive conflicts, particularly when this vision is shared by the upper class and the middle and working classes. If we compare (Table 8.4) the year 2008, which posted a peak in growth, with the year 1996, which marked the end of a deep economic crisis, we see a progression in the proportion of individuals whose perception leans towards the idea that wealth is expandable and does not give rise to distributive conflicts. This progression is situated at around 10 percentage points for the middle class, the working class and the lower class, as well as for the upper and upper-middle classes.

The opinion that an individual's income should be aligned with his or her efforts, coupled with the conception that wealth is expandable and the belief that wealth can be obtained by some without compromising the wealth of others, is consistent with the majority opinion that the government should have less of a stake in regulating income obtainment, which is best left to individuals. Here, nonetheless, we observe some differences between the middle and working classes and the upper and upper-middle classes (Table 8.5). After having assigned a more important role to the government with regard to the distribution of income in 1996 and 2001 (a period of a drop in income), in 2008 a lower proportion of the lower classes assigned a preponderant role to the government with regard to efforts to distribute income. 
TABLE 8.4 Perception of wealth as fixed or expandable (in percentage)

\begin{tabular}{|c|c|c|c|c|}
\hline & \multicolumn{2}{|c|}{$\begin{array}{l}\text { Middle class, } \\
\text { working class and } \\
\text { lower class }\end{array}$} & \multicolumn{2}{|c|}{$\begin{array}{l}\text { Upper class, } \\
\text { upper-middle class }\end{array}$} \\
\hline & 1996 & 2008 & 1996 & 2008 \\
\hline $\begin{array}{l}\text { One can become rich only at } \\
\text { the expense of others ( } 1 \text { to } 5 \text { ) }\end{array}$ & 33.8 & 22.8 & $29 \cdot 9$ & 18.9 \\
\hline $\begin{array}{l}\text { Wealth can be increased and } \\
\text { be sufficient for all ( } 6 \text { to 10) }\end{array}$ & 66.2 & $77 \cdot 3$ & 70.1 & 81.3 \\
\hline Total & 100 & 100 & 100 & 100 \\
\hline
\end{tabular}

SOURCE: AUTHOR'S ESTIMATES BASED ON THE WORLD VALUES SURVEY, 1996 AND 2008.

TABLE 8.5 The market versus state intervention (in percentage)

\begin{tabular}{|c|c|c|c|c|}
\hline & \multicolumn{2}{|c|}{$\begin{array}{l}\text { Middle class, } \\
\text { working class and } \\
\text { lower class }\end{array}$} & \multicolumn{2}{|c|}{$\begin{array}{l}\text { Upper class, } \\
\text { upper-middle class }\end{array}$} \\
\hline & 1996 & 2008 & 1996 & 2008 \\
\hline $\begin{array}{l}\text { People should have more } \\
\text { responsibility }\end{array}$ & 47.8 & 54.5 & $55 \cdot 9$ & 57.1 \\
\hline $\begin{array}{l}\text { The government should have } \\
\text { more responsibility }\end{array}$ & $5^{2.2}$ & $45 \cdot 5$ & 44.1 & 42.9 \\
\hline Total & 100 & 100 & 100 & 100 \\
\hline
\end{tabular}

SOURCE: AUTHOR'S ESTIMATES BASED ON THE WORLD VALUES SURVEY, 1996 AND 2008.

\section{Fiscal Policy as a Redistributive Instrument}

The downturn in Chinese growth, which had been one of the main drivers of growth in various countries in the region, has also implied the end of the cycle of high prices for raw materials and as such a significant drop in fiscal resources that will inevitably have repercussions that may lead to a contraction in public expenditure. It is in this new context of slower growth that it is likely 
that questions will be raised about the possible ways through which poverty and inequality could be reduced.

Latin America has often been characterised as the region with the world's highest level of income inequality. Nevertheless, it is important to note that the distribution of primary income or market income in the member countries of the Organisation for Co-operation and Economic Development (OECD) is as-if not more - unequal than that seen in many Latin American countries. It is also important to remember that fiscal policies and social expenditure are the mechanisms that offset, to a large extent, market disparities. In the case of Latin American countries, fiscal policy plays a very marginal role in attenuating income inequalities given that indirect taxes (on added value) predominate and are regressive by nature (Lustig et al., 2013b). Social expenditure has a redistributive impact on poor households but, as we have seen, its reach is very limited in Peru's case (Figure 8.20).

If we compare the situation in Peru with that of other countries in the region, it is evident that income taxes play a less important role than social expenditure, and than education and health expenditure in particular (Figure 8.21). Cash transfers are more important in Chile, Mexico, Uruguay and Brazil.

The margin for implementing policies via which to fulfil the dual objectives of reducing poverty and inequalities is very broad (Goñi et al., 2011; Blofield, 2011). Nevertheless, this option will hit a wall when it comes to generating

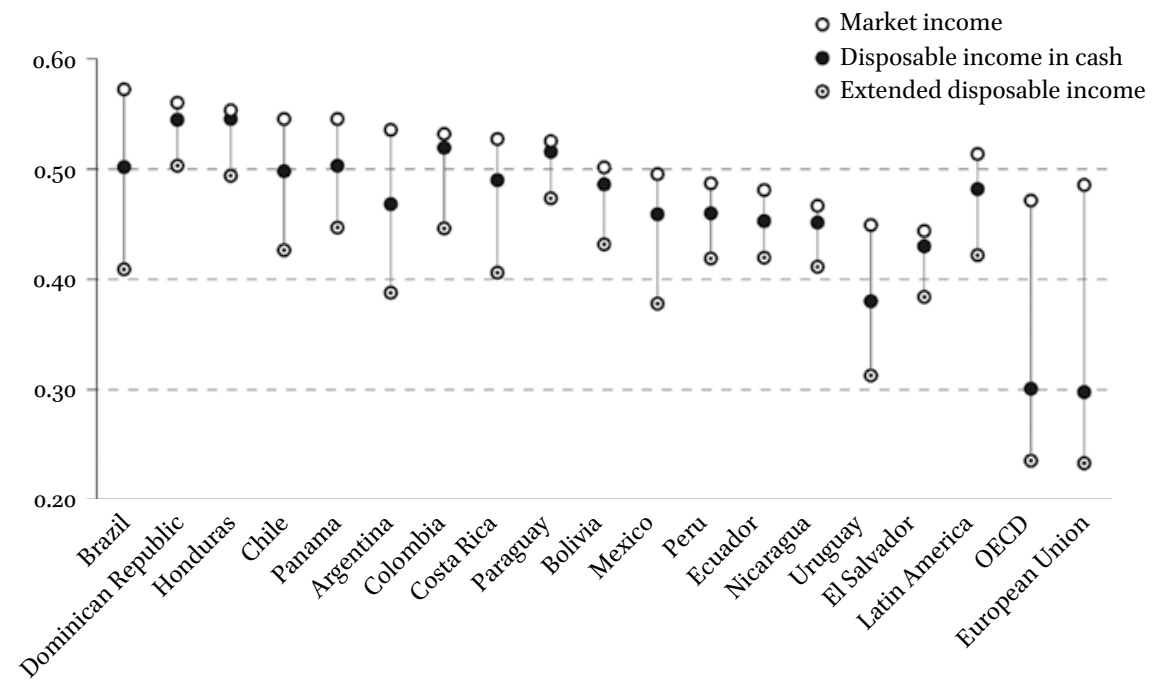

FIGURE 8.20 Effects of fiscal policy and social expenditure on health and education on income inequality (Gini coefficient) around 2011 (Latin America 16 countries, OECD-30 countries excluding Chile and Mexico, European Union-15 countries). SOURCE: ECLAC, IEF (2014, 47, FIGURE 13). 


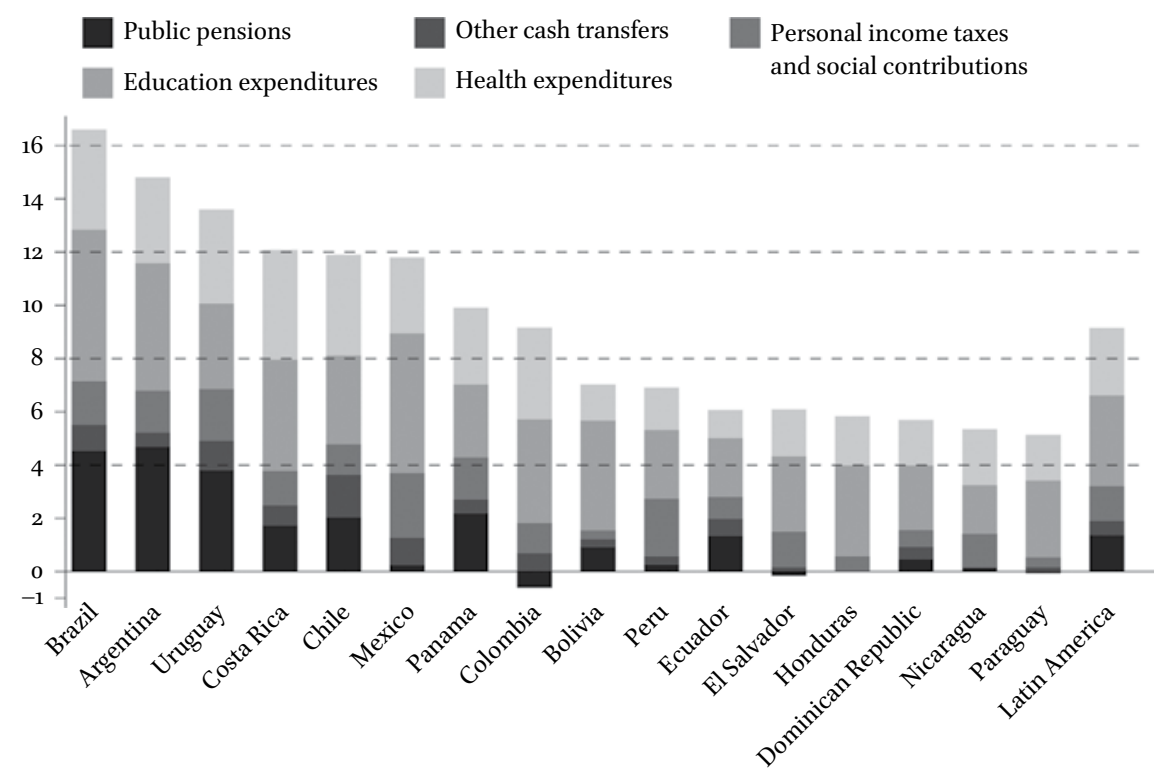

FIGURE 8.21 Reduction in the Gini coefficient according to fiscal policy instruments (in percentage points). SOURCE: ECLAC, IEF (2014, 49, FIGURE 14).

social consensus with regard to its timeliness and appropriateness. The findings regarding the perception of distributive justice and the role assigned to the market and that assigned to the state allows us to predict that redistributive fiscal policies have a long way to go before they can be institutionalised as policies that combat poverty and inequality.

\section{Conclusion}

In the new context of low growth, poverty reduction must be accompanied by policies that aim to reduce inequality - policies that must, on one hand, drive growth in productive activities for the internal market and, on the other, propitiate a demand shock through an increase in social expenditure. This will offer the additional benefit of contributing to reducing gaps in access to quality public goods, which will, in turn, reduce inequality of opportunities. The viability of an alternative strategy for development in this new context requires a different vision of tax policies, which — unlike the frameworks in place in neighbouring countries-have not been used as a policy instrument for achieving more redistributive justice. The amounts needed to close the poverty 
gap represented barely 2.9 per cent of the expenditure of non-poor households in 2015. It is commonly believed that after the spectacular reduction in poverty posted in the last decade, it may be more difficult to reduce poverty and inequality further given that the households that have yet to exit poverty fall very far below the poverty line. Nevertheless, this idea does not hold up if we test the data: the aforementioned reduction in poverty was accompanied by a reduction in poverty gaps. The low level of indebtedness and the reserves accumulated during high-growth phases (in terms both of currencies and of fiscal reserves) provide a wide margin for applying distribution policies via more social expenditure, improving quality coverage for education and health and universalising social programmes (Pension 65 and Cuna Mas, among others). The redistributive effect of both types of interventions in the countries of the region falls significantly short of that observed in OECD countries.

The Peruvian case combines a strong dependency on raw materials with direct distributive policies (conditional transfer programmes) and indirect distributive policies (distribution of the canon ${ }^{5}$ and mining and oil royalties to local authorities). The vulnerability of this social model will become manifest in the new phase of weak or moderate growth and will simultaneously affect fiscal income and its distributive capacity as well as household incomes. In this context, where the tax rate and the fiscal base are low and social expenditures barely increase, the fragility of the growth model will not be remediated without a social pact in favour of better distribution of income, which entails increasing fiscal pressure on income to finance social expenditure in favour of the poorest homes. The current political context in Peru, and the population's preferences, are unlikely to favour this option. Nevertheless, problems of public safety, which are without a doubt associated with an unequal distribution of the fruits of growth, have become a top priority among the population and may pressure the Peruvian state into practicing more redistribution or more repression. The new government will have to resolve this dilemma.

\section{Annex}

\section{Non-parametric Decomposition of the Variations of Poverty: Growth and Redistribution*}

This method is based on the link that exists between the Lorenz curve and the cumulative density function (cdf). As pointed out by Maasoumi and

5 The government transfers half of the taxes collected from the mining industry to the regions and municipalities where the minerals are extracted. This is what is called the 'canon'. 
Mahmoudi (2013), the cdf function can be used to highlight the redistribution effect given that the Lorenz curve (normalised for the average value) is nothing more than the inverse of the distribution function:

$$
\mathrm{L}(\mathrm{p})=1 / \mu \quad \operatorname{cdf}^{-1}(\pi) \mathrm{d} \pi .
$$

Given that it is postulated that cdfi and cdf 2 have the same average value, Maasoumi and Mahmoudi (2013) show that

The portion of the change in the incidence of poverty that can be attributed to growth is summarised, according to the authors cited, with the following expression:

The variation in the poverty rate is equal to

$$
\Delta P=P\left(F_{2} ; z\right)-P\left(F_{1} ; z\right)
$$

The intersection between the vertical line (of poverty) and the $F_{1}$ curve gives us (on the axis of the coordinates) the incidence of poverty $\left(\mathrm{H}_{1}\right)$.

A new curve is constructed $\left(\mathrm{F}_{1}^{*}\right)$ of accumulated frequency (cdf), multiplying the expenditures of all of the households $\left(\mathrm{F}_{1}\right)$ by the average rate of expenditure growth.

Percentage of the population

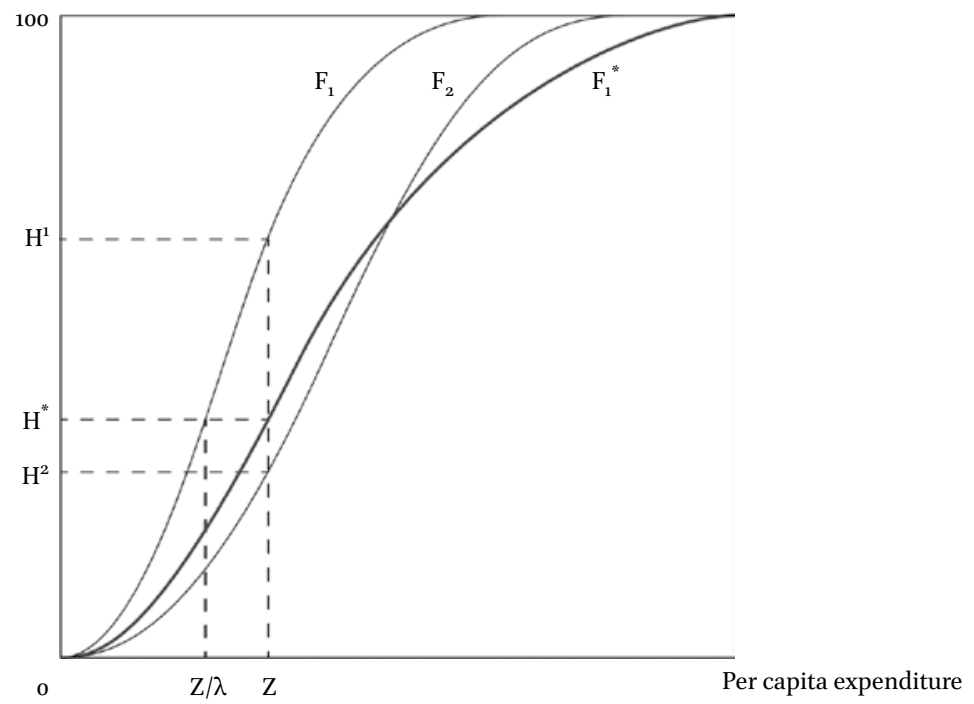

FIGURE A.8.1 Growth and redistribution decomposition of poverty change. SOURCE: MASSOUMI AND MAHMOUDI $(2013,268-276)$.

*Note: To prevent the index number problem, the 'average' effect is calculated after averaging the decomposition obtained after increasing the initial distribution and that obtained by reducing the final distribution. 


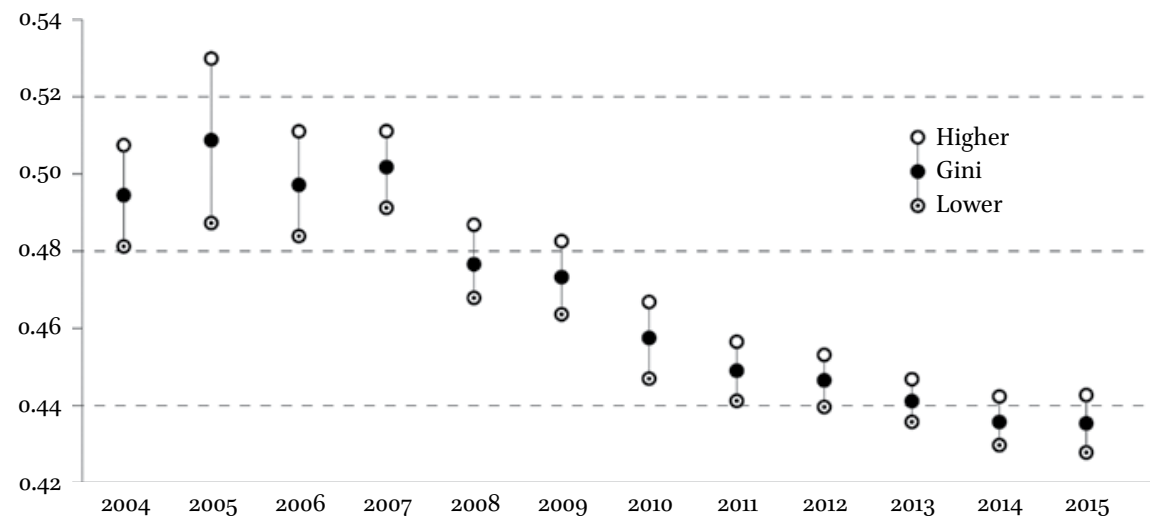

FIGURE A.8.2 Gini coefficient of income and its confidence intervals (at 95\%), 2004-15 (Peru). SOURCE: AUTHOR'S ESTIMATES BASED ON ENAHO, 2004-15.

Note: Income at prices in Metropolitan Lima.

Confidence intervals calculated using the bootstrapping method.

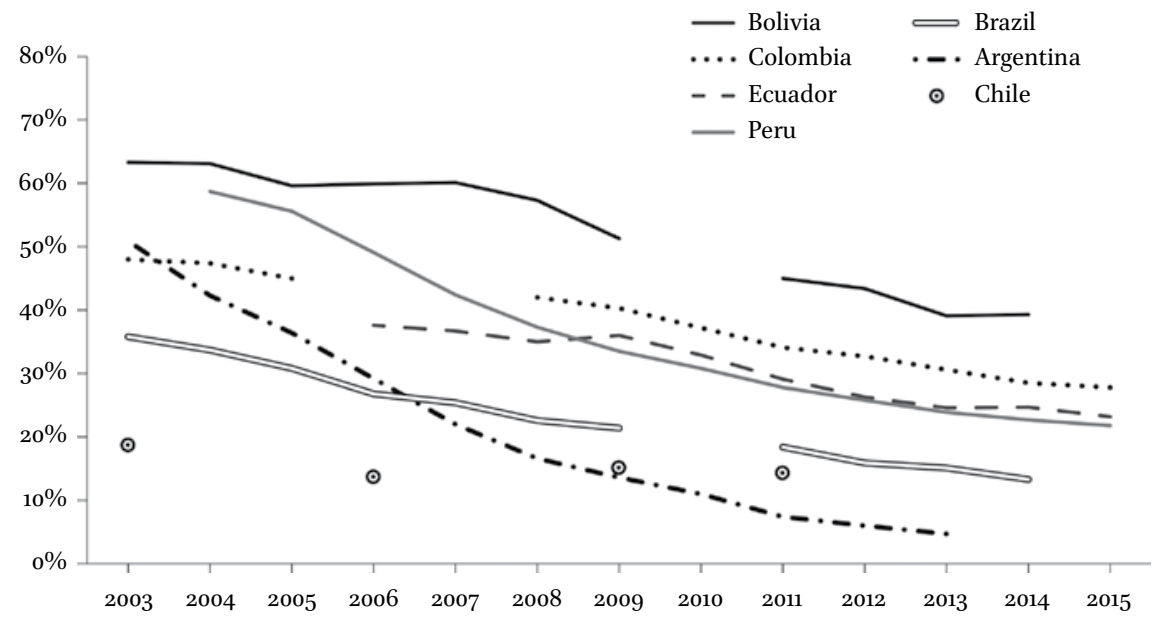

FIGURE A.8.3 Evolution of poverty (national poverty lines), 2003-15 SOURCE: SEDLAC DATABASE. 
TABLE A-1 Decomposition of poverty and inequality indicators according to income source (relative contribution)

PERU, 2004, 2010, 2015

\section{FGT(o) FGT(1) Gini Theil}

\begin{tabular}{lrrrr}
\hline 2004 & $39.3 \%$ & $14.6 \%$ & 0.491 & 0.469 \\
2010 & $21.4 \%$ & $6.8 \%$ & 0.457 & 0.398 \\
2015 & $15.1 \%$ & $4.5 \%$ & 0.435 & $0.35^{2}$ \\
Variations & & & & \\
$2004-2010$ & -17.9 & -7.8 & -0.034 & -0.071 \\
$2010-2015$ & -6.3 & -2.3 & -0.022 & -0.046 \\
$2004-2015$ & -24.2 & -10.1 & -0.056 & -0.117
\end{tabular}

RELATIVE CONTRIBUTION

2004-2010

Labour income

Remittances and private donations

Imputed rent

Extraordinary earnings

Transfers and public donations

Total variation

$\begin{array}{rrrr}\text { FGT(o) } & \text { FGT(1) } & \text { Gini } & \text { Theil } \\ 80 \% & 78 \% & 40 \% & 43 \% \\ 9 \% & 8 \% & 20 \% & 31 \% \\ 4 \% & 5 \% & 20 \% & 19 \% \\ -1 \% & -7 \% & -11 \% & -19 \% \\ 9 \% & 16 \% & 31 \% & 26 \% \\ 100 \% & 100 \% & 100 \% & 100 \%\end{array}$

2010-2015

Labour income

Remittances and private donations

Imputed rent

Extraordinary earnings

Transfers and public donations

Total variation

$\begin{array}{rrrr}52 \% & 37 \% & 32 \% & 73 \% \\ 0 \% & -2 \% & 9 \% & 2 \% \\ 14 \% & 15 \% & 0 \% & 0 \% \\ 0 \% & 5 \% & 9 \% & -23 \% \\ 33 \% & 46 \% & 50 \% & 48 \% \\ 100 \% & 100 \% & 100 \% & 100 \%\end{array}$

2004-2015

Labour income

Remittances and private donations

$\begin{array}{rrrr}71 \% & 65 \% & 37 \% & 58 \% \\ 6 \% & 4 \% & 16 \% & 17 \% \\ 8 \% & 9 \% & 12 \% & 8 \% \\ -1 \% & -4 \% & -7 \% & -25 \% \\ 16 \% & 26 \% & 40 \% & 41 \% \\ 100 \% & 100 \% & 100 \% & 100 \%\end{array}$

Imputed rent

Extraordinary earnings

Transfers and public donations

Total variation 


\section{References}

Azevedo, J.-P., V. Sanfelice and M.C. Nguyen (2012) Shapley Decomposition by Components of a Welfare Measure (Washington, D.C.: World Bank), mimeo.

Azevedo, J.-P., V. Sanfelice and G. Inchauste (2013a) Decomposing the Recent Inequality Decline in Latin America, Policy Research Working Paper 6715 (Washington, D.C.: World Bank), http://documents.worldbank.org/curated/en/59766146805454306o/ Decomposing-the-recent-inequality-decline-in-Latin-America (accessed on 14 September 2016).

Azevedo, J.-P., G. Inchauste, S. Olivieri, J. Saavedra and H. Winkler (2013b) Is Labor Income Responsible for Poverty Reduction? A Decomposition Approach, Policy Research Working Paper 6414 (Washington, D.C.: World Bank), http://documents.worldbank .org/curated/en/882051468340821632/Is-labor-income-responsible-for-poverty-re duction-a-decomposition-approach (accessed on 14 September 2016).

Barros, R., M. de Carvalho, S. Franco and R. Mendonça (2006) 'Uma análise das principais causas da queda recente na renda brasileira', Econômica, 8(1), pp. 117-147.

Blofield, M. (ed.) (2011) The Great Gap: Inequality and the Politics of Redistribution in Latin America (Pennsylviana: Pennsylviana State University Press).

Bourguignon, F. (2015) 'Appraising income inequality databases in Latin America', Journal of Economic Inequality, 13(4), pp. 557-578, DOI: 10.1007/s10888-015-9304-4.

de Ferranti, D., G. Perry, F. Ferreira and M. Walton (2004) Inequality in Latin America: Breaking With History? World Bank Latin American and Caribbean Studies (Washington, D.C.: World Bank), https://openknowledge.worldbank.org/han dle/10986/15009 (accessed on 14 September 2016).

de la Torre, A., E. Levy Yeyati, G. Beylis, T. Didier, C. Rodriguez Castelan and S. Schmukler (2014) Inequality in a Lower Growth Latin America, LAC Semiannual Report, October (Washington, D.C.: World Bank), https://openknowledge.worldbank.org/ handle/10986/20413 (accessed on 14 September 2016).

ECLAC, IEF (2014) Los efectos de la política fiscal sobre la redistribución en América Latina y la Unión Europea, Colección de Estudios №8 (Madrid: Programa EUROsociAL), http://sia.eurosocial-ii.eu/files/docs/1412088027-Estudio_8_def_final.pdf (accessed on 1 July 2017).

Foster, J.-E. and M. Wolfson (2010) 'Polarization and the decline of the middle class: Canada and the U.S.', Journal of Economic Inequality, 8, pp. 247-273, http://hdl.handle.net/10.1007/s10888-009-9122-7.

Gasparini, L., G. Cruces, L. Tornarolli and M. Marchionni (2009) A Turning Point? Recent Developments on Inequality in Latin America and the Caribbean, Working Paper 81 (La Plata: CEDLAS), http://cedlas.econo.unlp.edu.ar/archivos_upload/doc_ced las81.pdf (accessed on 14 September 2016). 
Gasparini, L. and N. Lustig (2011) The rise and fall of income inequality in Latin America, Working Paper 118 (La Plata: CEDLAS), http://cedlas.econo.unlp.edu.ar/ download.php?file=archivos_upload/doc_cedlas118.pdf (accessed on 14 September 2016).

Goñi, E., H. López and L. Servén (2011) 'Fiscal Redistribution and Income Inequality in Latin America', World Development, 39(9), pp. 1558-1569, DOI: 10.1016/j. worlddev.2011.04.025.

IMF (International Monetary Fund) (2016) World Economic Outlook. Too Slow for Too Long. (Washington, D.C.: IMF).

Inchauste, G., J.-P. Azevedo, B. Essama-Nssah, S. Olivieri, T. Van Nguyen, J. SaavedraChanduvi and H. Winkler (2014) Understanding Changes in Poverty. Directions in Development-Poverty (Washington, D.C.: World Bank), https://openknowledge .worldbank.org/handle/10986/19445 (accessed on 14 September 2016).

Kakwani, N., M. Neri and H.H. Son (2009) Linkages between pro-poor growth, social programs and labour market: the recent Brazilian experience Research Paper 2009.26 (Helsinki: UNU-WIDER), http://hdl.handle.net/10419/45140.

López-Calva, L.F. and N. Lustig (2010) Declining Inequality in Latin America: A Decade of Progress? (Washington, D.C.: Brookings Institution Press).

Lustig, N., L.-F. López-Calva and E. Ortiz-Juárez (2013a) 'Declining Inequality in Latin America in the 200os: The Cases of Argentina, Brazil, and Mexico', World Development, 44, pp. 129-141, DOI: 10.1016/j.worlddev.2012.09.013.

Lustig, N., C. Pessino and J. Scott (2013b) The Impact of Taxes and Social Spending on Inequality and Poverty in Argentina, Bolivia, Brazil, Mexico, Peru and Uruguay: An Overview, CEQ Working Paper 13, http://econ.tulane.edu/RePEc/pdf/tuli313.pdf (accessed on 15 September 2016).

Maasoumi, E. and V. Mahmoudi (2013) 'Robust growth-equity decomposition of change in poverty: The case of Iran (2000-2009)', The Quarterly Review of Economics and Finance, 53, pp. 268-276.

Ravallion, M. (2016) The Economics of Poverty: History, Measurement and Policy (New York and Oxford: Oxford University Press).

Székely, M. and P. Mendoza (2015) 'Is the Decline in Inequality in Latin America Here to Stay?' Journal of Human Development and Capabilities, 16, pp. 397-419. DOI: 10.1080/19452829.2015.1050320.

World Bank (2016) Global Economic Prospects (Washington, D.C.: World Bank).

Yamada, G., J.-F. Castro and J.-L. Bacigalupo (2012) 'Desigualdad monetaria en un contexto de rápido crecimiento económico: El caso reciente del Perú', Revista Estudios Económicos, 24 (Lima: Banco Central de Reserva del Perú), pp. 65-77, http://www .bcrp.gob.pe/docs/Publicaciones/Revista-Estudios-Economicos/24/ree-24-yamada-castro-bacigalupo.pdf (accessed on 15 September 2016). 
Zepeda, E., D. Alarcón, F. Veras and R. Osorio (2009) Changes in earnings in Brazil, Chile, and Mexico: disentangling the forces behind pro-poor change in labour markets, Working Paper $5^{1}$ (Brasilia: International Policy Centre for Inclusive Growth), http://www.ipc-undp.org/pub/IPCWorkingPaper51.pdf (accessed on 15 September 2016). 